\title{
Historical Archaeologies of the American West
}

\author{
Kelly J. Dixon
}

Published online: 19 January 2014

(C) The Author(s) 2014. This article is published with open access at Springerlink.com

\begin{abstract}
Historical archaeology in western North America includes a vast collection of research that underscores the region's dynamic cultural heritage. Here, I review a sample of the literature related to this research and organize them into four conceptual themes: colonialism and postcolonialism, landscape transformation, migration and diaspora, and industrial capitalism. I conclude that the future of historical archaeology in the West will be grounded in research that integrates these themes. As the region continues to experience human dilemmas related to issues such as balancing resource extraction with sustainable conservation and lingering issues of colonialism, these archaeologies have value for transcending the natureculture divide and for understanding the ways in which humanity can navigate pressing issues relevant to our modern world, including vulnerability, risks, adaptation, resilience, and sustainability.
\end{abstract}

Keywords American West · Historical archaeology · Aridity · Colonialism . Diaspora - Industrial capitalism - Global change - Landscape transformation . Migration

\section{Introduction}

[We] trap out the beaver, subtract the Mandan, infect the Blackfeet and the Hidatsa and the Assiniboin, overdose the Arikara; call the land a desert and hurry across it to get to California and Oregon; suck up the buffalo...kill off the nations of elk and wolves and cranes and prairie chickens and prairie dogs; dig up the gold and rebury it in vaults somewhere else... kill Crazy Horse, kill Sitting Bull; harvest wave after wave of immigrants' dreams and send the 
wised-up dreamers on their way; plow the topsoil until it blows into the ocean; ship out the wheat; ship out the cattle; dig up the earth itself and burn it in power plants and send the power down the line...dry up the rivers and springs, deep drill for irrigation water as the aquifer retreats...(Frazier 1989, pp. 209-210).

The epigraph above- "the punch line of two hundred years on the Great Plains"-brutally summarizes the swift and vast changes that have taken place in the American West over the last several centuries (Frazier 1989, pp. 209-210; see also Worster 1991, pp. 4-6). The outcomes of these relatively sudden and dramatic transformations in the American West have relevance for decisions we make today (cf. Rockman and Flatman 2012) and underscore our growing sense of obligation to address questions related to anthropogenic influences on the environment. Analysis of Spanish California's 18th-century mission complexes, for example, has drawn attention to the ways that churches, outlying structures, and fields served as vectors for floral and faunal invaders that sparked ecological transformation of the landscape (Allen 2010b, pp. 69-70).

Four common theoretical themes have emerged from historical archaeological inquiry on the American West: colonialism and postcolonialism, landscape transformation, migration and diaspora (with subthemes of transnationalism, identity, and ethnogenesis), and industrial capitalism. Four intertwined subthemes of industrial capitalism (extractive industries, labor, transportation, and communication) often intersect with the first three themes. Examples of such studies are categorized in Table 1, yet these often crosscut the four themes, serving as a reminder that integration of these themes is essential to practicing historical archaeology in the region. For example, analyses of gender are often couched within a framework of various topics that include race and class, colonialism, and agency (e.g., Cooper and Spude 2011; Dixon 2005; Hardesty 2010, 2011a; King 2011; Lightfoot 2005; Mills and Martinez 1997; Mullins 2008a; Praetzellis and Praetzellis 1992a, 2001; Silliman 2004; Thornton 2011; Timmons 2007; Voss 2008a, b; Wilkie 2010).

Western historians have long been concerned with many of the topics listed in Table 1, emphasizing issues related to aridity, extractive industries, dependence on the federal government, and the mythic quality of the so-called western "frontier" (Guy and Sheridan 1998; Malone 1989). These regional historians are generally divided into "Old" and "New" Western historians. Turner's (1893) essay, "The Significance of the Frontier to Western History," sparked a century of debate between Old Western historians, who considered this to be a "cornerstone" of Western history, and the New Western historians who objected to Turner's views because they overlooked a more "shameful side of the westward movement" (Worster 1991, p. 10; see also Hall 2009; Hardesty 1980, 1985, 1991a; Lazarus 1991; Lightfoot 1995; Lightfoot and Martinez 1995; Limerick 1987, 1991, p. 62; Robbins 1991, 1994). Much of the history of the region was overtly influenced by myths, many of which were perpetuated by dime novels, the media, and booster propaganda, whereby nonindigenous residents of the West promoted the influx of outside capital, manipulating associated rhetoric to serve their own interests (Brooks and Prine 1996, p. 89; Dixon 2005, 2006; Schablitsky 2007). 
Table 1 Examples of historical archaeological topics in the American West

\begin{tabular}{|c|c|}
\hline Topic & Sample sources \\
\hline Battlefields & Laumbach et al. (2001); Scott (2005); Scott et al. (1989); Wilcox (2009) \\
\hline Diasporas & $\begin{array}{l}\text { Chung and Wegars (2005); Dixon (2011); González-Tennant (2011); } \\
\text { Greenwood and Slawson (2008); Merritt (2010a); Schulz and Allen (2008); } \\
\text { Voss (2005); Voss and Allen (2008); Wegars (1993) }\end{array}$ \\
\hline Overland emigration & $\begin{array}{l}\text { Dixon et al. (2011); Hardesty (1997); Hawkins and Madsen (1990); Novak } \\
\text { (2008) }\end{array}$ \\
\hline Forts & Merritt (2010b); Mills (2008); Mueller (2011) \\
\hline Gender roles & $\begin{array}{l}\text { Chung (1998); Hardesty (1998a, 2010); Purser (1991); Spude (2005, 2011); } \\
\text { Timmons (2007); Voss (2008b) }\end{array}$ \\
\hline Great Depression & Alanen (2000); White (2012) \\
\hline $\begin{array}{l}\text { Historic inscriptions/ } \\
\text { rock art }\end{array}$ & Turpin (1989); Urbaniak and Rust (2009) \\
\hline Homesteading & $\begin{array}{l}\text { Buechler (1990); Church (2002); Clark (2011); Haught (2010); Heilen and } \\
\text { Reid (2009); Kroll (2012); Mallios (2009); Towner and Creasman (2010) }\end{array}$ \\
\hline Labor & $\begin{array}{l}\text { Camp (2011b); Ludlow Collective (2001); Saitta (2007b); Silliman (2004); } \\
\text { Spielmann et al. (2009) }\end{array}$ \\
\hline Mining & Hardesty (1991b, 2003, 2010); Spude et al. (2011) \\
\hline Missions & $\begin{array}{l}\text { Allen (1998, 2010a); Arkush (2011); Blind et al. (2004); Lightfoot (2005); } \\
\text { Spielmann et al. (2006) }\end{array}$ \\
\hline $\begin{array}{l}\text { Ranching, Vaqueros, } \\
\text { Cowboys }\end{array}$ & $\begin{array}{l}\text { Fischer (2007); Pavao-Zuckerman and LaMotta (2007); Ziesing (1997); see } \\
\text { also Clayton et al. (2001); Starrs (1998) }\end{array}$ \\
\hline $\begin{array}{l}\text { Mortuary behavior, } \\
\text { memory }\end{array}$ & $\begin{array}{l}\text { Chung and Wegars (2005); Connolly et al. (2010); Kraus-Friedberg (2008, } \\
\text { 2011); Mallios and Caterino (2007, 2011); Novak (2008) }\end{array}$ \\
\hline Urbanization & Delgado (2009); Ringhoff and Stoner (2011) \\
\hline Transportation & $\begin{array}{l}\text { Corbin (2006); Corbin and Rodgers (2008); Griffin and Gurcke (2011); } \\
\text { Hammer (2011); Van Tilberg (2007) }\end{array}$ \\
\hline
\end{tabular}

The 1960s cultural milieu spawned the New Western History, and the difference between traditional and New Western History (e.g., Brooks 2002; Brugge 1985; Clayton et al. 2001; Gutiérrez 1991; Hall 1989; Hämäläinen 2003, 2008; Hurtado 1996; James and Raymond 1998; Johnson 2000; Limerick 1987; Murphy 1997; Robbins 1991, p. 186; Rohe 1982, 1996; Van Kirk 1984; West 1998; White 1991a, b; Worster 1994; Wrobel and Steiner 1997; Zappia 2012) can best be summarized as the "West of mountain men, cowboys, Indians, gunfighters, prospectors, and outlaws" versus the new, "counterclassic history of wage earners, women, minorities, urbanization, industrialization," and colonialism (Hardesty 1991a, p. 4; see also Silliman 2005).

New Western historians' research is making contributions to American Indian, African American, Asian American, Latin American, feminist, environmental, legal, social, and urban history (Limerick 1991, pp. 64-65). Likewise, historical archaeology in the West is also making contributions to these and related topics (Chicone 2011a, b; Clark 2011; Dixon 2011; Lee et al. 2002; Ludlow Collective 2001; Mallios 2009; Praetzellis and Praetzellis 2001; Truett 2004; Zedeño 2007). Historical archaeology's tendency to emphasize power relations, class, race, and gender (Little 1994; Orser 1999, 2007, 2010; Paynter 2000a, b) has created a 


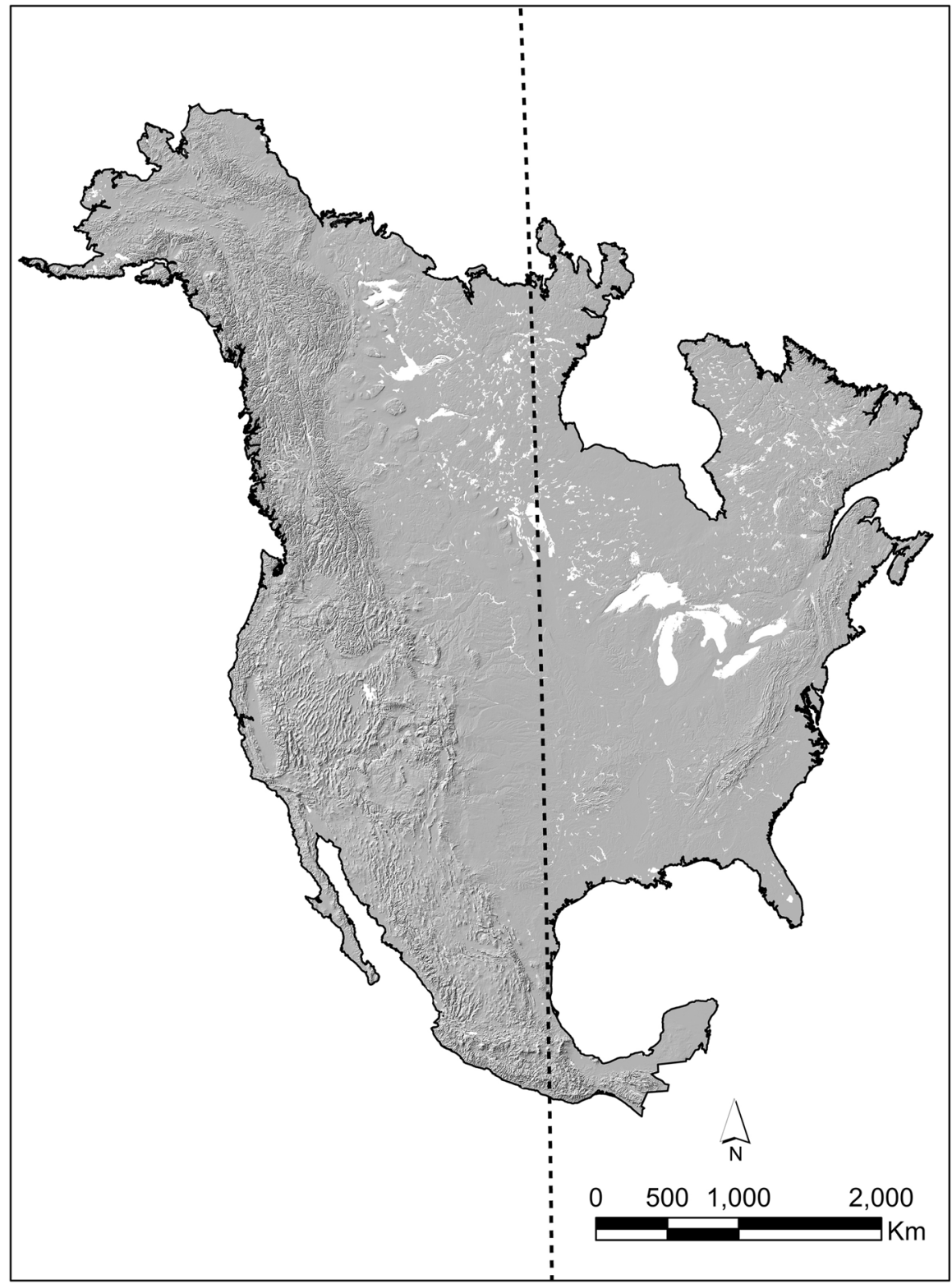

Fig. 1 Map of North America with the "American West" situated west of the 98th meridian, inserted as the dashed line running through the center of the continent (map courtesy of Diane Whited)

bibliography that parallels that of Western historians, fostering opportunities for collaborative research between the overlapping areas of inquiry shared by the New Western historians and historical archaeologists (James 2012).

The Northern American West itself, as a region, requires a brief introduction. The definition of the "American West" evolved as the United States expanded 


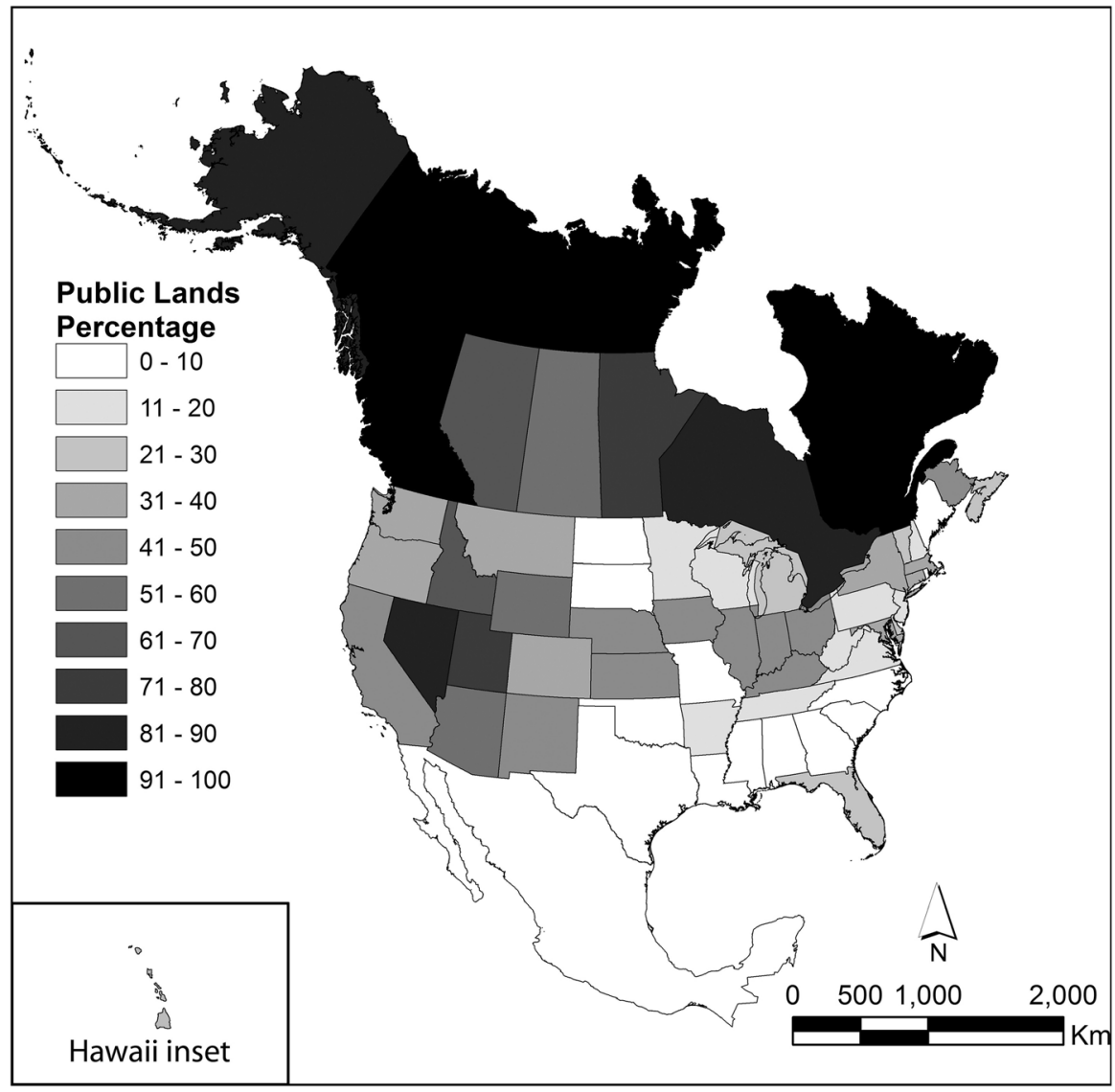

Fig. 2 Map showing the amounts of public land across North American states and provinces, shown as a percentage of total state land area (map courtesy of Diane Whited)

westward, extending from the Appalachians prior to the 19th century, then to the Mississippi River during the 19th century, then to the Pacific Coast, and then to the Rocky Mountains and Great Basin in the late 19th and early 20th centuries (Beck and Haase 1989; Hardesty 1985, 1991b; Pomeroy 2008; West 1994). Here I define the American West as the geographical area situated west of the 98th meridian (Fig. 1) in North America, and including the Great Plains, the Rocky Mountains, the Great Basin, the desert Southwest (Sonoran, Mojave, and Chihuahua Deserts), the Pacific Coast, the temperate rainforests of the Pacific Northwest, Alaska, and, technically, Hawai'i (see also Fischer 2007, p. 372; Hardesty 1991a, p. 3; Meinig 1998). The western United States encompasses over half of the land area of the nation, and significant portions of these states are public land (Fig. 2). Canada and Mexico also have a "West," including the area south of the U.S.-Mexico border and remote reaches of the Yukon and Alaska. Nevertheless, the archaeological examples examined here primarily represent projects from the western United States. 
My focus is on anthropological and archaeological sources, as well as some geographical and historical sources, with an emphasis on works published during the first decade of the 21 st century. Nevertheless, the examples I present are a rather small sample of the important archaeological research on the American West. Thanks to an "explosion of information... [in] contemporary historical archaeology" (Orser 2010, p. 112) —and in the American West-I had to be selective and unfortunately leave out the research of many exceptional anthropologists, archaeologists, bioarchaeologists, geographers, historians, and preservationists. Because of the abundance of archaeological research being carried out daily in the American West by academic and consulting archaeologists, the resulting gray literature fills agency libraries with multidisciplinary data. When possible, I include gray literature in this discussion, but access to this material is limited to my own past work and research, along with the fact that gray literature is not necessarily centralized.

Readers interested in delving into the region's gray literature should contact state historic preservation offices (SHPOs) and tribal historic preservation offices (THPOs) to gather additional reference material pertinent to topics of interest. Because historic preservation offices have partnered with interdisciplinary teams to produce summaries of site types and related research domains, there are sources available via these agencies that can be used as springboards for archaeological research (e.g., Brooks and Jacon 1993; Church et al. 2007; Lindström et al. 2007; White et al. 1991). In addition, there are metabases, such as tDar (The Digital Archaeological Record) by Digital Antiquity (www.digitalantiquity.org), where researchers can delve into troves of information about the West's many archaeologies. Even so, given the amount of literature, these just scratch the surface.

Most examples presented here date from the past several centuries, a period referred to as "modern world archaeology" (Orser 1996, 2010) but commonly known as "historical archaeology." Most practitioners of "historical" archaeology in the American West study, promote, manage, and preserve cultural heritage associated with the proto- and post-Columbian period of transition, when "complex interdigitations of cultures and practices" (Hall and Silliman 2006, p. 4; but see Lightfoot 1995, p. 200) were - and still are-rampant in the region (Carter et al. 2005; Thackeray 2012; Warner and Baldwin 2004; Wilcox 2009, 2010a, b; Zimmerman 2007).

\section{Colonialism and postcolonialism}

Considering that the eastern United States (and much of eastern Canada) developed under European influence, the lands in the American West represented the first "true" colonies of the United States (Corbin and Rodgers 2008, p. 7; see also Jordan et al. 1997, p. 4). Colonialism is distinct from colonization. Colonization refers to processes of migration and settlement, which inherently included "contact" between the colonizers and the colonized. Colonialism, on the other hand, involves power, such as the exploitation of people and lands in one region by people from another. "Colonialism is the major cultural and historical fact of the last 500 years and to some extent the last 5000 years...," and although we purportedly live in a postcolonial world, the economic, social, and intellectual consequences of 
colonialism and memory politics endure (Gosden 2004, pp. 5-6; see also Orser 2010, p. 138; Silliman 2005).

Archaeological theoretical discussions recently emphasized the lingering context of colonialism where American Indians and Canadian First Nations “...continue to be second-class citizens in the cultural resources world of North America...in a system supposedly designed to protect their heritage..." (Watkins 2003, p. 283; see also Hegmon 2003 and Moss 2005; but see examples of long-term success in Prentiss 2012). The complex repercussions of colonialism are evident in recent archaeological studies in the American West (Allen 2010a, b; Carter et al. 2005; Liebmann 2006; Lightfoot 2005, 2006; Mills and Martinez 1997; Pavao-Zuckerman and LaMotta 2007; Rothschild 2006; Silliman 2004, 2005; Thomas 1989; Wilcox 2002, 2009, 2010a, b; Zimmerman 2007), revealing the influence of postcolonial theory on archaeology (Orser 2010, p. 136). Postcolonial approaches question the "knowledge about and the representation of colonized 'Others' that has been produced in colonial and imperial contexts," providing a "theoretical stance" to investigate and challenge the discourses of colonialism (Liebmann 2008, pp. 2-4).

In reaction to "internal dialogues and external critiques" calling for increased involvement of descendant communities (Nicholas and Hollowell 2007, p. 59), postcolonialists strive to contribute to our understanding of colonial experiences, emphasizing the agency of indigenous peoples and investigating the ethnogeneses that have developed amid the context of colonialism (Liebmann 2008, p. 2). Even though modern archaeology is laden with a worldview that is grounded in Western science, amid the postcolonial theoretical climate, it is a discipline that is clearly "bereft without embracing other ways of...knowing and doing as valid alternatives" (Nicholas and Hollowell 2007, p. 61, 64; see also Blackhawk 2006). Such alternatives may include tools for sustainability and will require data from sociohistorical contexts in which most historical archaeologists work, which tend to be contexts where indigenous peoples are marginalized and subordinated to dominant structures and policies, with many places still feeling their effects (Orser 2010, p. 136). Figure 3 shows the reservations where many of these communities reside; please note that there are a number of indigenous groups in the West not represented in Fig. 3, since those groups remain unrecognized by the federal government. Those reservations represent a new set of cultural landscapes (e.g., Ambler et al. 2008; Medicine Crow 2003; Neihardt 1979; Old Coyote and Old Coyote 2003; Stands in Timber and Liberty 1969), set against the backdrop of mainstream and predominantly Eurocentric Western narratives.

When the Spanish arrived and established the colony of New Mexico in 1598, they found a region already settled and subsequently documented Pueblo, Navajo, Apache, and Ute people and villages (Liebmann 2006; Preucel 2002; Spielmann et al. 2009; Staski 2005; Wilcox 2009). Indian-Spanish interactions in colonial New Mexico during the 16th and 17th centuries were not without conflict. In August 1680, after living for 80 years under Spanish subjugation, Pueblo leaders in New Mexico planned an insurrection - the Pueblo Revolt-launching a series of attacks on Spanish civil and religious institutions throughout north-central New Mexico. Surviving Spanish fled to El Paso del Norte, making this one of the most successful indigenous revolts in the history of the Americas. In 1692, the Spanish returned with 


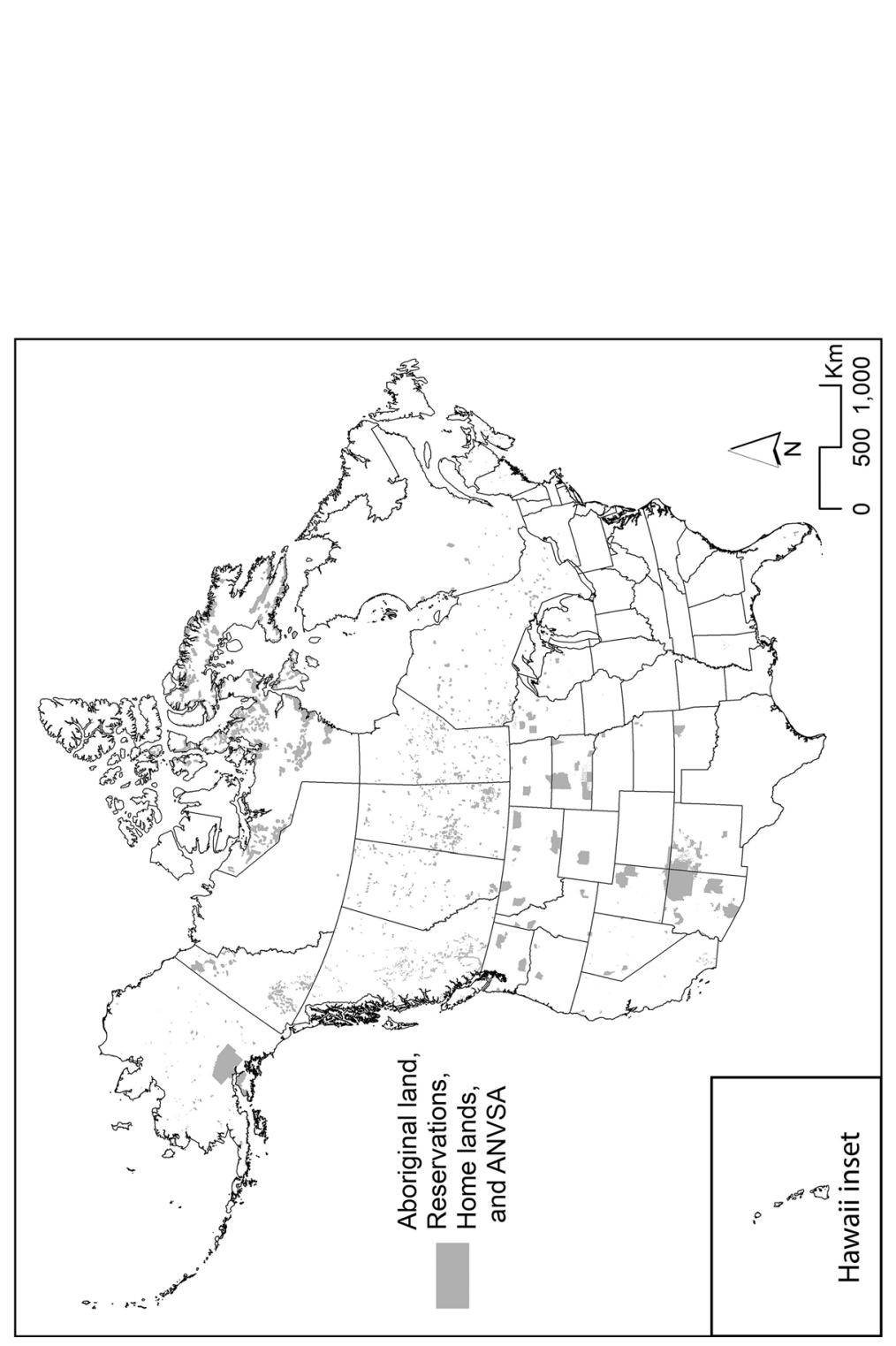

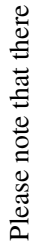

总 
hordes of colonists and indigenous allies; however, to avoid any more insurrections, the Spanish authorities recognized Pueblo land rights and permitted indigenous religious practices (Wilcox 2009), driving a postcolonial revitalization movement among Pueblo people in the American Southwest (Liebmann 2006).

Integrated archaeological evidence, oral native histories, and written records of events surrounding the 1680 Pueblo Revolt also support the argument that Puebloan peoples were never conquered. Rather, during the 16th and 17th centuries they successfully resisted Spanish hegemony and survived with their cultural identity intact by reoccupying sites on defensive mountainous terrain that had agricultural potential, was extensively occupied during prehistory, and provided safety during times of stress (Wilcox 2009, p. 28; see also Kulisheck 2003; Preucel 2002; Reséndez 2005).

Centuries after the Pueblo Revolt, American colonization sprawled across the Great Plains and into Intermountain West between the Rocky Mountains and the Sierra Nevada. Abundant material remains of this late 19th-century expansion, and its subsequent impact upon indigenous peoples, dominates the archaeological record of this area (Hardesty 1991b, p. 29). By the mid-1860s, transportation routes and settlement drastically increased across the western two-thirds of the nation as more Americans than ever before resumed the quest for land, gold, and commerce. The hundreds of military posts (i.e., "forts") established throughout the American West, particularly those established prior to the Spanish-American War (1898-1901), were created to "control" American Indians (Frazer 1965, pp. xix-xxiii). "The showdown between the older Americans and the new, between two ways of life that were basically incompatible, was at hand...," and when given the choice to surrender or fight, many chose to fight (Stewart 2005, p. 321). The decades of skirmishes, pursuits, massacres, raids, expeditions, and battles between the U.S. Army and allied tribal nations in the American West in the years following the Civil War has come to be known as "the Indian Wars." Archaeological and bioarchaeological investigations of associated battlefield landscapes have yielded evidence about the art of war as well as violent expressions of culture contact (Fawcett and Lewelling 2000, pp. 43-44; Fox 1993; Fox and Scott 1991; Greene and Scott 2004; Laumbach 2001; Laumbach et al. 2001; Liebmann 2006; Madsen 1985; Merritt 2010a; Merritt et al. 2013; Milter 2013; Preucel 2002; Scott 1994; Scott et al. 1989; Scott and McFeaters 2011, p. 118; Wilcox 2009).

The Sand Creek Massacre represents another scene of violence from this period. On November 29, 1864, during the Pike's Peak Gold Rush, volunteers from Colorado's First and Third Regiments, under the command of Methodist minister and Civil War veteran Major John Chivington, attacked an unsuspecting encampment of Cheyenne people, including the villages of Chiefs Black Kettle and White Antelope along Sand Creek in eastern Colorado, slaughtering hundreds of Cheyenne villagers, "mostly women and ...fleeing children [who] became moving targets for marksmen, and several still-living Cheyenne were scalped..." (Thomas 2000, p. 53). The site of the Sand Creek Massacre still evokes the intensely personal and spiritual nature of the place and is sacred ground for Cheyenne and Arapaho (Greene and Scott 2004; National Park Service 2012; see also Nighthorse Campbell 2005; Whitacre 2005). 
The Rosebud and Little Bighorn battlefields are among many other sacred places associated with this era. These battles, like the massacre at Sand Creek, were linked with a mining boom. The 1870s Black Hills Gold Rush, with boomtowns like Deadwood, South Dakota, caused thousands of emigrants to flood into the Black Hills, which had been granted to the Sioux in the 1868 Treaty of Fort Laramie. During the winter of 1875, the Sioux, allied with Northern Cheyenne, spent the winter off reservation, on traditional hunting grounds, including areas in what is today southeastern Montana. Orders were sent out that any such groups needed to be back to reservation land within a few months or be considered hostile. Soon thereafter, the U.S. Army set out to locate those who had not returned to the reservation. Aware of being pursued by the soldiers, Northern Cheyenne, Sioux, and Arapaho allied to defend their villages.

On June 17, 1876, just one week before the Little Bighorn Battle and about 30 miles away, a battle took place along Rosebud Creek (Battle of the Rosebud), which is one of the largest battles fought between the U.S. Army and Native American forces during the "Great Sioux War," with 1,000 soldiers assisted by 300 Crow and Shoshone warriors against 1,500 Cheyenne, Sioux, and Arapaho warriors. The Cheyenne, Sioux, and their allies unified and amassed their forces to face the Army; their efforts were successful at the Rosebud, as they sparked enough fatigue and damage to cause the U.S. command to return to base camp near Sheridan, Wyoming. As a result, that command did not join up with and provide backup for the Seventh Cavalry under George Armstrong Custer at the Little Bighorn the following week (Merritt et al. 2013). Archaeological research associated with the Little Bighorn Battlefield has contributed greatly to the numerous histories of that battle and demonstrated the relevance of systematic archaeological research to forensic firearms analysis, military history, Native American studies, and Western history (Fox 1993; Scott et al. 1989, p. xiii; see also Scott 2005; National Park Service 2012). Interdisciplinary studies of these and other battlefields (Laumbach et al. 2001; Scott and McFeaters 2011; Scott et al. 1998; Wakeman and Laumbach 1997) are stark reminders of the many ways of remembering and documenting just one event, with "some of the most striking examples of individuated perspectives on the landscape" coming from archaeological analyses of battlefields (Pauls 2006, p. 70). Indigenous histories of those battles provide compelling evidence that demonstrates such individuated perspectives (e.g., Neihardt 1979, pp. 70-99; Powers 2011; Welch and Stekler 2007; Wooden Leg 2003).

The examples presented above are among countless "microhistorical" shades of the recent colonization in the American West (see also Beaudry 2011; Brooks et al. 2008). To more completely understand the intersection of these microhistories, colonialism, and the wars fought over the region's important places, it is important to consider other military endeavors. The U.S. Army was scattered throughout the American West at hundreds of small forts, posts, outposts, and stations. In addition, the Spanish conquistadores also established presidios and missions where archaeological investigations have revealed intersections of colonialism, landscape transformation, migration and diaspora, and industrial capitalism (Ayres 1995; Bertando 1997; Blind et al. 2004; Cordell and Fowler 2005; Farnsworth 1989; Staski 1998). Much of this research has long been associated with "contact" studies because these tended to be outposts that had daily interactions with local, 
indigenous groups, but these were much more than "contact" situations (Silliman 2005). Rather, they were complex processes, an understanding of which is necessary for critical, informed, and sophisticated archaeologies of the American West. Research related to archaeologies of colonialism (i.e., indigenous archaeology) is becoming more prevalent (Carlson 2006; Carter et al. 2005; Kulisheck 2003; McDonald et al. 1991; McNiven and Russell 2005; Silliman 2004, 2005; Warner and Baldwin 2004; Watkins 2000; Wilcox 2009, 2010a, b), and helping "shift the register" to better understand the "process of colonization from the perspective of the colonized" (Hall and Silliman 2006, p. 5; Lightfoot 2006).

Archaeology is one among several fields used in Lightfoot's (2005) historical anthropological study of California Indians to examine the ways in which past events affect living Indians today, such as issues related to acquiring tribal recognition. Using ethnohistory, ethnography, native texts, and archaeology, Lightfoot found little evidence to support the assertion that coastal Indians of central and southern California had become culturally extinct or entirely "Hispanicized" as a consequence of their colonial experiences. Rather, he observed that indigenous peoples reproduced their cultural identities and practices despite Spanish colonial and Russian commercial endeavors, explaining his findings by underscoring that "native agency in colonial settings involved the dialectical struggle between native intentions and desires and the dominance hierarchies these confronted" (Lightfoot 2005, p. 19; see also Mills 2002).

In another case, centered on the investigation of a historic Spanish mission in southern Arizona, the Sobaípuri-O'odham people, who chose to adopt the new, mission-based way of life, became targets of hostility from "kindred who remained free and from groups of other affiliations that rejected attempts at missionization" (Seymour 2007, p. 293). The northern California Miwok dealt with another level of colonial transformations, working as field hands, cowboys, artisans, cooks, and servants on bustling livestock, agricultural, and manufacturing operations in Mexican California (Silliman 2001, 2004). Many other examples demonstrate the perseverance of "precontact" ways of life in California (Allen 1998; Arkush 2011; Gamble and Zepeda 2003; Hull 2009, pp. 218-219; but see Haley and Wilcoxon 2005). Cultural perseverance and continuity were similarly representative of life on the Canadian Plateau of British Columbia, where early 19th-century contacts between Secwepemc (Shuswap) people and fur traders occurred at a Secwepemc village established adjacent to the Hudson's Bay Company's Thompson's River Post. Archaeological excavations of several house pits in that village unearthed a small number of "European" artifacts, including such household goods as bottle glass and metal basins; raw materials such as pounded copper; personal items including glass beads, clay pipe fragments, brass pins, and buttons; and lead shot for hunting (Carlson 2006, p. 224). The application of postcolonial theory to examine the remains of this village and to emphasize local contexts and historical processes revealed subtle changes and a continuum of local, indigenous traditions that have characterized Salishan cultures in the British Columbia interior for thousands of years, "regardless of the acceptance of some of the material items of colonial powers" (Carlson 2006, p. 238). The strategies that the Secwepemc people developed during the fur trade era fostered an indigenous cultural identity despite the overall changes brought about by colonial expansion. 
Several other examples demonstrate instances of resilience, continuity, and the maintenance of cultural identities throughout the recent colonial period (Oland et al. 2012; Preucel 2002; Reséndez 2005; Spielmann et al. 2009; Schrieber and Mitchell 2010; see also Lightfoot 2005); my final example comes from architectural interpretations of structures on the Crow Reservation in eastern Montana. There, a powerful narrative associated with the young chief Plenty Coups' vision quest to Montana's Crazy Mountains in the 1850s helped shape and add meaning to the built environment created by and for Crow (Apsáalooke) people as they moved onto reservation land in south-central Montana in the early 1880s; in turn, this became an example of the ways in which the Crow coped with and survived the onslaught of regional environmental transformations brought about by ranching, extractive industries, and water control (Carter et al. 2005, pp. 97-98).

Relevant archaeologies of colonialism and the accompanying influence of postcolonial theories can, certainly, help "shift the register" (Hall and Silliman 2006, p. 5) in the American West by including indigenous landowners in the identification, documentation, and interpretation of archaeological resources. The value of such collaborative endeavors has been duly noted, with applications including interdisciplinary research into topics such as fire ecology (Mason et al. 2012), where traditional ecological knowledge (TEK) was integral to the biological and fire scientists' understanding and management of cultural landscapes and traditional cultural places (see also Zedeño and Bowser 2009).

Such interdisciplinary ventures provide a model for the ways in which TEK and information from the natural and social sciences can be integrated to transcend the nature-culture divide and to better understand and prepare for human vulnerability, risks, adaptation, resilience, and sustainability over time, particularly as humanity continues to coexist with inevitable environmental changes (e.g., Flores 2001). The methods fueling such avenues of inquiry will need to be drawn from the "maturing relationships" (cf. Murray 2011) between scientific techniques and indigenous ways of knowing (e.g., Ross and Pickering 2002; Silliman 2005; Tarka 2007; Tsuli and Ho 2002: Turner et al. 2000). Saitta (2007b) argued that, as a method, it is imperative to consider diverse knowledge systems not as competitive but as a means of evaluating "truth-claims" by converging diverse knowledge systems. Many of these diverse knowledge systems converge and sometimes collide when it comes to land use and landscape, particularly considering the relevance of postcolonial archaeologies of landscape transformation to broader social and environmental issues.

\section{Landscape transformation}

Environmental archaeological research on the American West demonstrates the impacts of "ecological and biological transformation" that accompanied colonization (Allen 2010a, p. 90). Each wave of settlers-intentionally or not-brought increasing numbers of foreign biological and cultural menageries in the form of flora, fauna (including domesticated beasts of burden, beetles and other insects, parasites), disease, religion, colonialism, capitalism, and industrialization. Collectively, these generated relatively sudden landscape transformations, with European 
plants and weeds swiftly dominating coastal California in less than a century (Allen 2010a, pp. 69-70; see also Melville 1994).

In a synthesis of environmental and economic historical archaeologies, Mrozowski (2010) drew attention to the ways in which capitalism, colonialism, and industry have collectively impacted the environment. The introduction of cattle to vulnerable locations like Hawai'i provides an example of the ways that newcomers had dramatic effects on the islands' ecosystems, as well as Native Hawaiians, who "confronted a new world of alien biota, shifting social and economic relations, and eventual political subjugation" (Fischer 2007, p. 372). The cattle industry transformed not only the landscape but also the economy of Hawai'i, fueling colonial expansion into the Pacific (Fischer 2007, p. 372; see also Mills 2002 and Mills and Martinez 1997; Orser 2012).

Perhaps one of the more important considerations when looking at humanenvironment interactions in the American West is the fact that various groups, often drastically foreign to each other, came into relatively sudden contact and each had culturally constituted perceptions of land and landscape (e.g., Church 2002, p. 223; Makley and Makley 2010; Thomas 2005; Weisiger 2004; see also Anschuetz et al. 2001; Basso 1996; Pred 2008). What was sacred to some became a source of profit for industrialists and new homes for many settlers for whom the land also became sacred.

Landscape transformations that took place over the past several centuries (and millennia) have much to teach us about land use in the West, providing parables with relevance to modern world concerns, particularly those related to climate change, with place-based lessons of "landscape learning" (Rockman and Steele 2003). Archaeological studies of the last 500 years offer opportunities to document the transformation of nature into culture (through the process of learning), which can, in turn, be placed into a pedagogical set of tools to outline culturally and historically informed conservative conservation ethics and protocols that span vulnerability to sustainability (Hardesty 2003, p. 81; Rockman and Steele 2003; Rockman and Flatman 2012). The interdisciplinary nature of the archaeology of the historical period in the American West can serve as an interpretive bridge to understand the relatively rapid natural and cultural changes occurring before, during, and after the last 500 years of colonialism, industrial capitalism, and their intertwined repercussions of migration and landscape transformation (Hardesty 2010, pp. 183-184; see also Hämäläinen 2003; O’Connor 2004).

When Europeans, Asians, and Africans began global diasporas in the 15th century, they sparked changes that have shaped the modern world, including an "army of biological agents who silently began their own colonizing efforts" (Mrozowski 2006, p. 23; see also Orser 2010, 2012). Icons of the recent natural history of the American West, horses and tumble mustard (tumbleweeds), represent only two of the vast numbers of fauna and flora introduced during the last several centuries. The earliest documented emergence of "Old World" plants and animals in California dates to the mid-18th century, when Spanish and Mexican colonization introduced the mission system to the region in what is today southern California. Even though historians tend to agree that most European plants in California date from after the 1848-1849 Gold Rush, Allen's (2010b, p. 71) research indicates that 
"rapid ecological change occurred in the lands surrounding the Franciscan missions, well before the Gold Rush and the later American occupation." Biogeographical studies have similarly found that Mediterranean annuals moved into California before the first missions were founded (Mensing and Byrne 1998).

Landscape transformations from European-introduced plant species in central Mexico took over 300 years, and "the magnitude of the change, good and bad, was almost greater than the mind could encompass or the heart endure. The metamorphosis was more than political or religious or intellectual or technological; it was biological" (Allen 2010b, p. 78; Crosby 1994, pp. 47-48). In comparison, the archaeological record at several California missions has indicated that such alterations took just over 70 years in coastal California and had a "profound effect on both the native and nonnative human population" (Allen 2010b, p. 78; see also Crosby 2005).

The reintroduction of the horse to North America in the 17th century left a wake of cultural and ecological changes, particularly among Plains tribal groups, who rapidly incorporated horses into their daily lives (e.g., Haines 1938; Osborn 1983). The spread of horse culture to the Plains began with the expulsion of the Spanish from New Mexico during the Pueblo Revolt in 1680, at which time the victorious Pueblo Indians captured thousands of horses and other livestock and then traded the animals to the Plains Indians (Haines 1938, pp. 429-431). In a relatively short time, groups such as the Comanche adapted to a fully mounted, nomadic lifestyle by the 1730s (Hämäläinen 2003, 2008). Other indigenous Plains groups soon adopted horses into their lifestyles, creating a powerful and iconic ethnogenesis based on the return of the horse to North America (Hämäläinen 2003).

While American Indian groups experienced an ethnogenesis by way of introduced livestock, Spanish colonists, even with all of their European imports, struggled in the new landscape. While settling among the Pueblo villages in New Mexico, the Spanish built homes, estancias (ranches), Franciscan missions, planted crops, raised livestock, and imported ceramics, tools, and textiles (Trigg 2004, p. 223). Throughout most of the 17th century, documentary sources indicate distress at a Spanish colony in New Mexico, with the land Eurocentrically described as "sterile, lacking in everything necessary to support human life," with crops failing year after year, with a "great many Indians perished of hunger, lying dead along the roads, in the ravines, and in their huts...," and with the colonists low on food because their herds were dying (Trigg 2004, p. 223). Despite this foreboding transition, the initial Spanish presence persisted for almost a century before the colony was abandoned after the Pueblo Rebellion of 1680 (see discussion above). Colonists soon realized that finding food in these unfamiliar environments required practical decisions about their cuisine, and they became dependent on indigenous people. In turn, indigenous people coped with relatively extreme landscape transformations and changing social relations associated with the influx of "people intent on acquiring their lands," which had long represented the basis of their food production (Trigg 2004, pp. 245-246).

During the 18th century, the Navajo (Diné) in the Four Corners area integrated Spanish livestock, namely, sheep and goats, into their lives. This was a significant change, as the people living in this area were not yet pastoralists when the Spanish 
arrived - they were farmers. As pastoralism took hold, growing numbers of flocks caused families to spread out across the region, promoting the adoption of transhumance, an ancient pastoral pattern involving seasonal migrations to various ecological zones to sustain herding in arid lands (Weisiger 2004, p. 253). This lifestyle was distinct from the Diné's Apache forebears, but it had repercussions. By the early 20th century, the booming population of livestock sparked the consequences of overgrazing, which meant the landscape could no longer sustain vigorous forage. Conflicts associated with grazing areas increased, and, in this case, pastoralism eventually proved unsustainable (Weisiger 2004, p. 270). The Diné story gives pause for reflection, especially considering that the lesson of an unsustainable practice in one of the West's arid regions took less than three centuries.

Another example draws attention to the fact that U.S. land use laws generated in the well-watered East ineffectively governed settlement in the arid West (Church 2002, pp. 222-223). Indigenous residents, Spanish-speaking New Mexican (Hispaño) settlers, and European American homesteaders interacted with land and water in diverse ways amid southern Colorado's arid environment. Even though each group had different ways of dealing with landscape transformations, all skirted federal law concerning homestead settlement since those laws were inappropriate for subsistence in an arid region. When Spanish-speaking New Mexicans came to southern Colorado in the 1860s-1870s, they were accustomed to an indigenousinfluenced way of dealing with aridity, whereby each family had both irrigable and nonirrigable lands, with territory divided along river bottoms into private holdings. Then, through inheritance over generations, these were further subdivided into smaller strips, but they all still had water frontage. As a result, northern New Mexico villages displayed a vernacular, long, narrow field pattern resulting from generations of such inheritance (Church 2002, p. 226). On the other hand, the U.S. one-mile-square Township and Range arbitrary grid system, established by the Northwest Ordinance in 1787, was integral to the Homestead Act of 1862 since that relied on land bounded "regularly and arbitrarily, with no consideration of water availability, local topography, arability, or grazing potential" (Church 2002, pp. 226-227). The indigenous-inspired, Hispaño ways of living in an arid environment were far more suitable for the land than laws created for the East's relative abundance of rainfall (Fig. 4).

Lack of rainfall and scarcity of easily accessible water did not deter the groups rapidly colonizing arid lands in the American West, especially those seeking to capitalize on the region's extractive industries, which became harbingers of landscape transformation in the region. The decaying remains of these types of archaeological sites can be used as labs for fleshing out valuable information about landscape transformations stemming from the intersection of extractive industries, capitalism, urbanization, labor, and identity (e.g., Spude et al. 2011), but also about human ecological studies of risk, adaptation, and innovation. Many of the West's extractive industries tended to be situated in arid areas with low and/or unpalatable water supplies, and so complex engineering systems became prevalent to support mining ventures and the infrastructure accompanying those ventures. The wellwatered East relied upon relatively simple water-gathering systems, but the West's 


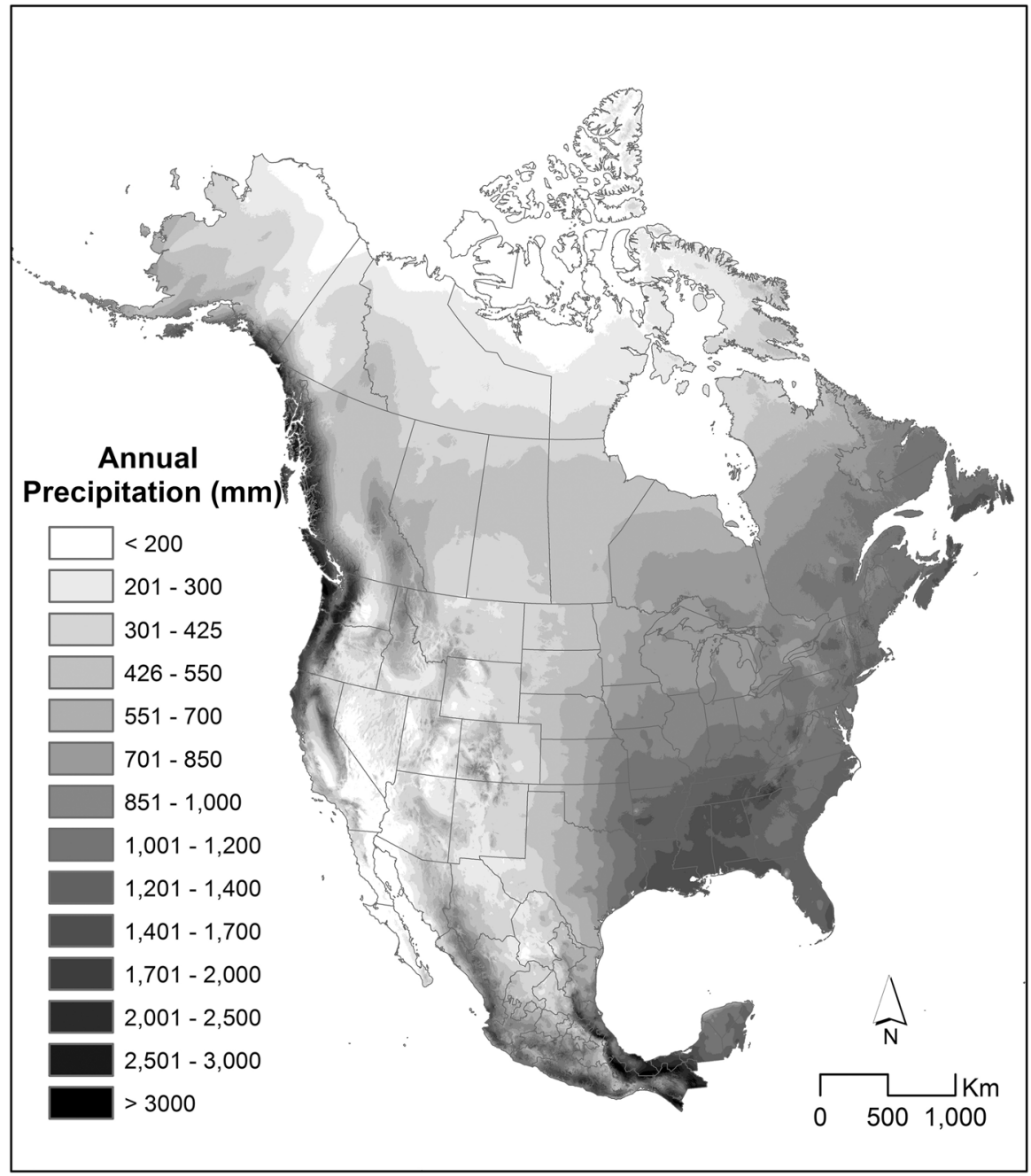

Fig. 4 Map showing a summary of the annual rainfall in North America between 1950 and 2000, showing the distinct change that occurs around the 100th meridian, with the well-watered East receiving much more annual rainfall than the arid West (map courtesy of Diane Whited; climate data available at $<$ http://worldclim.org/current>

"low volume of streams" required "complex and extensive water-gathering systems consisting of flumes, ditches, and canals...sometimes...dozens of miles long...[drawing] water from several watersheds" (Reynolds 1996, p. 6; see also Dixon 2005, pp. 82-87; Schamberger 1969). Water supplies, population growth, urbanization, and industrialization were all factors that fueled significant landscape changes in the mining West (Hardesty 2003, 2007). On the one hand, those landscapes represent drastic changes to indigenous ways of life (e.g., Hattori 1998). On the other hand, the mining landscapes themselves are stunning examples of 
humanity's earth-moving and water-controlling capabilities and have become historically significant and worthy of documentation (Ballard 2004; Baxter 2002; Mills 2011; Noble and Spude 1992; Quivik 2000, 2003, 2007; White 2003). Examples include hydraulic mining ventures that created "badlands," such as the Malakoff Diggins, an industrial capital enterprise known for drastically reconstructing landscapes in the foothills of northern California's western Sierra Nevada (Hardesty 2003, p. 84; see also Baxter and Allen 2005). The Berkeley Pit in Butte, Montana, an open-pit copper mine opened in 1955 by the Anaconda Company, was the largest truck-operated open-pit mine in the U.S., 1,600-feet deep and spanning $7,000 \times 5,600$ feet. The pit closed in 1982 and by the 1990s superfund cleanup was [and still is] underway. Butte's mining landscape can be seen as an industrial artifact, with its complexes of industrial buildings, linear/transportation corridors, neighborhoods, and topographical features (e.g., mine cuts, Berkeley pit, waste dumps). Analyses of these industrial landscapes are becoming more relevant to the modern world's concerns with how best to navigate anything from global changes to energy needs (Quivik 2000, 2007).

There has been resilience of some natural resources in areas affected by mining, with one example coming from Death Valley, California. An environmental (soils) study of Death Valley's historical mining landscapes indicated that there was a relatively fast, roughly 70-year recovery of native plants in some-but not allmining communities that went bust and were abandoned in one of the area's mining districts (Brown 2000; see additional discussion in Hardesty 2007). Although there is much more environmental archaeological work to be done on soils associated with mining sites, it is also crucial to accept the reality that the region's landscapes "may return to a similar condition over a given period of time, but will never again contain exactly the same suite of plants, animals, and general environmental conditions" (Fisher et al. 2009b, p. 6; see also Locke and Deardon 2005).

Mining and other extractive industries required railroads to transport materials to and from work camps and urban centers, and railroads caused yet another series of landscape changes (Merritt et al. 2012). There were thousands of rail lines-large and small gauge-leaving extensive dendritic networks of railroad grades, trestles, and tunnels throughout the West. These not only altered the landscape in the immediate wake of the rail lines themselves but also swiftly and conveniently transported resources, supplies, information, and people in and out of the region.

Places like the globally significant waterfront and gold rush port of San Francisco, California, demonstrate maritime travel's influence on the creation of urban landscapes. Using data from buried ships and collapsed buildings from the 19th-century boomtown's wharves, Delgado (2009) explored the rapid rise of San Francisco from 1849 to 1856 , arguing that the discovery of gold was not necessarily an instigator of the city's growth as it changed from a small village of a few hundred to a "city of thousands" in a few years (Delgado 2009, p. 1). The "Bay Area" underwent an accompanying coastal landscape transformation that created a new maritime environment with the Yerba Buena cove (San Francisco Bay), which had the appearance of a forest of masts and rigging from hundreds of wooden ships anchored throughout that cove (see also Arnold and Keyes 2000; Pastron and Delgado 1991). 
A poignant example of all that can be learned from the West's well-preserved urban archaeological resources, San Francisco's Gold Rush maritime origins and buried waterfront survived as an archaeological site, buried beneath the ruins of several catastrophic fires, 22 million cubic yards of landfill, and urban development. "The rapid pace of change and the massive amount of physical redevelopment of Yerba Buena into San Francisco completely erased most traces of the Gold Rush city" (Delgado 2009, p. 113), but archaeological investigations have revealed the fate of numerous old ships that burned and/or were trapped and buried by the landfill used to build up the original waterfront (see also Byrd et al. 2012). Maritime archaeological studies, as well as urban redevelopment, in places like Anchorage, Portland, San Diego, San Francisco, Santa Fe, Tucson, and Seattle, promise to expand our understanding of urbanization and transportation hubs-and the landscape transformations they heralded-within the web of colonialism, industrial capitalism, and modernization in the American West (e.g., Fitzsimons 1996; Hess 1996; Roth 2000; Shapiro 2008; Thiel 2002; Williams 1996). The droves of people passing through and building these cities moved into the region from all reaches of the globe, representing a series of large-scale migrations and diasporas worthy of their own theme.

\section{Migration and diaspora: Transnationalism, identity, and ethnogenesis}

Migration refers to the processes related to vast numbers of settlers flooding into a region. Published historical archaeological studies of overland emigration "sites" are relatively few considering the impacts this process had on the American West (Buck 1994; Hardesty 1997; Hawkins and Madsen 1990; Lingenfelter 1986; Morgan 1963). A small number of emigration events ended in tragedy, such as the Donner Party's ordeal with survival cannibalism (Dixon et al. 2010, 2011; Grayson 1990; Hardesty 1997, 2011b; Johnson 1996; Willey and Hardesty 2000; see also Goodyear 2006) or the Mountain Meadows Massacre (Novak 2008; Novak and Kopp 2003). These unfortunate episodes endure as popular tales of the risks taken by settlers traveling overland, adding fuel to the "mythic aura" of the region (Malone 1989; Wylie 1993). Despite such accounts of trepidation, desperation, and violence, waves of settlers continued to move into the region.

Diaspora generally refers to the dispersion of people from their original homeland. People from Africa, Asia, Europe, and Mexico rapidly colonized the American West from various parts of the world, sometimes leaving unique archaeological signatures, such as Basque sheepherders, who left graphic carvings called arborglyphs, including names and dates, on aspen throughout areas like the Intermountain West (Crawford 2005; Mallea-Olaetxe 2000); or Chinese miners and woodcutters, who left distinctive stone hearths at their isolated, rural work camps (Merritt 2011; Smith and Dixon 2005); or Italian railroad workers who left distinctive stone ovens in their camps (Wegars 1991). These archaeological signatures provide examples of global connections, which have called for a transnational way of approaching migration and diaspora. 
The concept of transnationalism is inherently bound to any given diaspora, demonstrating the ways in which researchers need to trace the "flows of ideas, objects, services, and people" (González-Tennant 2011, p. 513) to understand the nuances of cultural changes that occurred as various groups became dispersed from their homelands. A transnational approach can be seen as one methodological tool to interpret resources related to diasporas throughout the world (González-Tennant 2011; cf. Orser 2007; Ross 2011; Voss and Allen 2008, p. 16). Recognizing that transnational frameworks require working with local heritage (including descendant) communities, engaging with other archaeologists and historians, as well as colleagues in African, American Indian, Asian, Chinese, Hispanic, Irish, etc., studies (cf. Voss and Allen 2008, p. 20), it is possible to integrate resources to better understand marginalized populations, particularly those with little or no related historical documentation about their cultural heritage. For example, in telling the story of the Hispanic population living in southeastern Colorado, Clark noted that their "status as nonlandowners mutes their documentary presence" (Clark 2011, p. xix), which, in turn, required methodological challenges to investigate Hispanic sites in that region. Clark's and other archaeological analyses continue to flesh out intricacies of transnational, cultural, economic, and engendered identities over the past few centuries amid colonial and environmental contexts (e.g., Burley et al. 1992; Church 2002; Dixon 2011; Fawcett and Lewelling 2000; Flexner 2012; Hardesty 1998a; Hattori 1998; Lightfoot 2005; Spude 2011; Voss 2008a, b).

Diaspora studies in the American West provide critical insights to "understanding the early composition and development of modern African American, European American, Hispanic, and Native American cultures" (Lightfoot 1995, p. 201). Examples presented in all themes of this article draw from research related to the experiences of various cultural groups in the West who tend to be underdocumented or misrepresented in mainstream histories of the region.

The history of Africans in the American West is as old as the recent colonization period being examined here, starting with the story of Estevanico (Esteban), an enslaved Moroccan traveling with Spanish conquistadores. Esteban's travels "initiated the tripartite meeting of Indian, Spanish, and Anglo cultures that was to shape much of the region's history" (Taylor 1998, pp. 28-29, 2000, p. 103). African Americans who moved to this region during the era of slavery tended to find more social and economic opportunity in western states and territories (Billington and Hardaway 1998, p. 240; Captain 1995, pp. 42-44). After the Reconstruction experiment "ended" in 1877, thousands of former enslaved people left the South and sought the opportunities of the West (see also Smith 2011).

People of African ancestry who lived in Virginia City, Nevada-and who visited the surrounding Comstock Mining District during the latter portion of the 19th century-found themselves amid a complex political climate that overtly and subtly pervaded many aspects of their lives, demonstrating a pattern of integration, marginal survival, and success (Dixon 2011; James 1998, pp. 7, 152-153). On the one hand, they appeared to have had more freedom and opportunity than people of color living in many other parts of the country in terms of economic successes and an overall tone of integrated living that often included neighborly acceptance. On the other hand, they consistently experienced racist undertones and overtly 
restrictive attitudes and laws (Rusco 1975, pp. 23, 42-44). In short, historical research has indicated that people of African ancestry lived amid a complex juxtaposition of integration and prejudice in the American mining West.

Such variation in the treatment of people of color was common elsewhere in the West, as noted by Schubert (1971, p. 411) in his examination of African American soldiers stationed throughout the region. The 25th Infantry Regiment, the Buffalo Soldiers, was stationed at Fort Missoula, Montana, between 1888 and 1898, where local folklore suggests they were treated well and with respect (Sorenson 2012, pp. 64-65). A recent analysis of a dump assemblage from Fort Missoula initially sought to better understand the material remains of the Buffalo Soldiers stationed there; however, the dump did not provide enough information to determine the sources of the historic trash in that site (Mueller 2011; see also Laumbach et al. 2001).

In another case from Oakland, California, urban archaeological excavations recovered remains of households occupied during the 1890s primarily by African American Pullman car porters working for the Southern Pacific Railway, the "aristocracy of African American railroad workers" (Praetzellis and Praetzellis 2001, p. 650). Among the materials excavated from this site were kitchenwares associated with genteel dining rooms and reminiscent of the Victorian era's culture of gentility. Even though status among African Americans at this time was by far more affiliated with education, rational morality, and a general denial of material wealth (see Captain 1995; Mullins 1999, p. 27), considering artifacts as an information system, as well as the sociohistorical context of this archaeological case, the porters' purchase of goods "above their status..." was explained as a "form of resistance among African Americans at this time, since being well dressed and furnishing one's home with genteel artifacts contradicted racist assumptions" (Praetzellis and Praetzellis 2001, pp. 645-646, 651).

A final example of an African diaspora archaeological investigation includes the work at the African American-owned Boston Saloon, which intended to build on the existing historical and political foundations for people of African ancestry in 19th-century Nevada (Dixon 2011; James 1998, p. 153; Rusco 1975). The archaeological remains of the Boston Saloon suggest that it was on the more elegant end of the city's saloon spectrum. Revisiting Praetzellis and Praetzellis' (2001) discussion, such remains can certainly be interpreted as contradicting and combating late 19th- and early 20th-century racist assumptions (Dixon 2005, 2011, pp. 128-130).

As is the case for other cultural groups discussed below, historians have established a contextual foundation for archaeological investigations of the African diaspora in the American West (e.g., Billington and Hardaway 1998; James 1998; Katz 1996; Lang 1998; Meredith 2007; Rusco 1975; Taylor 1998; see local research tools such as http://mhs.mt.gov/research/AfricanAmerican/AfricanAmericanInMT. asp). Even with such a foundation-and despite the fact that the most significant unforced migration of people of African ancestry occurred after 1849 as African Americans moved westward (Captain 1995, p. 55; Woods 1983)—there have been only a few archaeological examinations of postbellum free African and African American populations in the American West (e.g., Cox 2007; Dixon 2006, 2011; 
Guenther 1988; Mallios 2009; Praetzellis and Praetzellis 1992b, 2001; Wood et al. 1999). Archaeological studies of postemancipation life for people of African ancestry in the American West have the potential to expand our understanding of African American life in a racialized society (Barnes 2011, p. 5; see also Fennell 2011; Mullins 2008b).

The Chinese diaspora was the result of mass migrations of Chinese citizens, most of whom came from Guangdong province near the port city of Guangzhou (Canton) and who set up communities throughout western North America, as well as in Australia, New Zealand, and Hawai'i (Voss and Allen 2008, pp. 5-6, 8-9). In the U.S. mainland, the first wave of Chinese immigration was prompted by the California Gold Rush, starting with news of the 1848 discovery of gold at Sutter's Mill. Prior to 1849 , no more than 50 Chinese (mostly scholars, merchants, former sailors, and performers) lived in the continental U.S., most in urban port cities in the North Atlantic. After the Gold Rush, that number grew to over 20,000 by the early 1850s (Voss and Allen 2008, pp. 8-9).

Overseas Chinese archaeology has flourished over the past few years, with archaeological investigations into Chinese shipwrecks and maritime culture (Layton 2002; Van Tilberg 2007), mining ventures (Norman 2012), urban communities known as Chinatowns (Costello et al. 2008; Fosha and Leatherman 2008; Greenwood 1978, 1996; Praetzellis et al. 1987; Rossillon 2008), Chinese farm workers associated with the California Gold Rush (Van Bueren 2008), engendered approaches to material culture (Voss and Williams 2008; Wegars 1993, 2003), studies of material distribution (Michaels 2005; see also Yoffee and Crowell 2006), analyses of the anti-Chinese movement (Baxter 2008), investigations of social organization (Chen 2001; Merritt 2011), studies of railroad construction camps (Baxter and Allen 2008; Merritt et al. 2012; Rogers 1997; Rossillon 1984; Wegars 1991), and research comparing Chinese and Japanese salmon cannery workers' dining habits (Ross 2011). These topics illustrate the ways that archaeology has expanded our understanding of the diversity of Chinese experiences in the West. Archaeologists are fortunate that many of the challenges involved in such research have already been encountered by historians of the Chinese diaspora and by scholars in Asian studies and Asian American studies, whose theoretical and interpretive frameworks can guide archaeologists in their discipline's growing involvement in scholarship related to Overseas Chinese communities (Voss and Allen 2008, p. 5; see also Mullins 2008a).

Overseas Chinese archaeology is part of a broader subfield known as Asian American archaeology. The cross-cultural comparisons of Japanese and Chinese salmon cannery workers (Ross 2011) is one example among a growing field dedicated to fleshing out the distinctions between Chinese and Japanese identities and communities, as these and other Asian immigrants moved into the North American West. Such studies are well underway, with transnational political interpretations of ethnic (i.e., national) identity on gravestones associated with a Japanese plantation worker cemetery in Pāhala, Hawai'i (Kraus-Friedberg 2011), as well as transnational identity and mortuary material culture associated with the Chinese plantation worker cemetery in Pāhala, Hawai'i (Kraus-Friedberg 2008). Bringing 20th-century archaeology into focus, recent research at Japanese internment 
camps is providing avenues to better understand WWII-era social and cultural issues (Kamp-Whittaker 2010; Shew 2010; Skiles and Clark 2010).

Archaeological studies also have underscored Spanish colonial and Mexican American identities (Butzer and Butzer 2000; Camp 2011a; Church 2002, 2008; Clark 2005, 2011; Heilen and Reid 2009; George 2008; Voss 2008b, 2012; see also Villalpando 2002), with intriguing examinations of such topics as the significance and ubiquity of Hispanic influence on the western cattle industry (Clayton et al. 2001; Fischer 2007; Praetzellis and Praetzellis 2001; Ziesing 1997). Other examples involving Spanish colonial and Mexican American communities were already discussed above since they crosscut the colonialism and landscape themes.

There are numerous other colonizing groups who have been equally marginalized in most primary sources. Irish Canadians (Smith 2004; see also Pyszczyk 1989), Hawaiians (Bayman 2009; Mills 1996, 2008, 2009; Rogers 1993), Metís (Burley 1989, 2000; Burley et al. 1992, 1996; Hanks and Pokotylo 1989), Mormons (Leone 1973; Merritt 2006; Scarlett 1999, 2006; Scarlett et al. 2007), and Russians (Black 2004; Blee 1985, 1989, 1990; Blee et al. 1986; Mills and Martinez 1997; Veltre and McCartney 2002) are among some of the other groups representing diaspora populations with transnational connections and multicultural histories. Whether immigrants or people just passing through, this convergence of cultures from all over the world in the North American West was powerfully fueled by industrial capitalism.

\section{Industrial capitalism: An intersection of transportation, extractive industries, labor, and communication}

The major theoretical paradigms driving historical archaeological studies in general have spanned the symbolic (Deetz 1977) and commercial dimensions of material culture (Leone 1995), with much of the field emphasizing archaeologies of capitalism. Despite the Eurocentric nature of the study of capitalism (Orser 2010, p. 114, 2012), it is nearly impossible to overlook the power of industrial capitalism in the American West, especially considering such topics as extractive industries, labor, transportation, and communication (cf. Hardesty 2010; Purser 2011).

Exploration, transportation, and the establishment of outposts were among the first grappling hooks of colonization associated with an emerging capitalist economy that had foundations in mercantilism (Orser 2014). El Camino Real, the first long-distance route established by European colonists in the western hemisphere, spanned some 1,600 miles $(2,575 \mathrm{~km})$, connecting Mexico City with Santa Fe between 1598 and 1880. Although it fell out of use in 1880 because of the rise of railroads, archaeological investigations of this and other early transportation systems (e.g., Staski 2005, p. 231; White 1991b) have much to reveal about vectors for the social and ecological transformations described under the landscape transformation theme above.

Over 200 years after the Spanish created El Camino Real, Lewis and Clark's Corps of Discovery (1804-1806) set out on their epic journey. Archaeological studies of segments of the trails used by Lewis and Clark indicate that once the 
Corps of Discovery had to cross the Rocky Mountains and go overland instead of traveling via waterways, they took advantage of complex, existing prehistoric trail systems (e.g., Karuzas 2008; McLeod 1984; see also Hall et al. 2003; Karsmizki 2004; Saraceni 1998). They made their way to the region associated with the Oregon coast and spent the winter of 1805-1806 at Fort Clatsop along a Columbia River estuary, inland from the Oregon coast, compiling geographical and other information and preparing for the return trip. This was the United States' first military transcontinental expedition dedicated to exploring the American West's resources with an aim of economic exploitation (Fritz 2004; Ronda 1998, 2003).

Extractive industries soon followed, and archaeological analyses of these properties highlight the ways in which early transportation corridors across the American West facilitated resource extraction, with extractive industries accelerating "conquest" (Hardesty 1991b, p. 32). Mining and the fur trade have been prominent in the published literature related to studying the social and cultural nuances of extractive industries in the American West. Nevertheless, the ruins of many other extractive industries lay across the region's wide, open spaces, representing harbingers of industrial capitalism, transnationalism, landscape transformation (urbanization), and colonialism, including archaeologies of logging and lumbering sites (Dixon 1996; Dixon and McQueen 1997; Hunt 1982; Paullin 2007), charcoal making (Hill 1987; Lindström 1993; Reno 1996), ceramics operations (Allen et al. 2013; Matero 2012; Merritt 2006; Scarlett 2006; Scarlett et al. 2007), and irrigation and water control (Hardesty and Buhr 2001; Reynolds 1995, 1996).

The fur trade was the earliest wave of industrial capitalism to work its way throughout the region. By the first decade of the 19th century, the Louisiana Purchase inspired a fur trade boom in the Rocky Mountains and the Pacific Northwest. Furtrading outposts, including the Russian outpost at Fort Ross in northern California, were "typically founded by commercial companies that had in common an agenda of exploiting available resources (land, animal, mineral, and people) for great profits" (Lightfoot 2005, p. 7). Fur companies hired "mountain men" to travel to these regions to trap fur-bearing animals and/or trade with Indian trappers.

During the late 18th and early 19th centuries, two British companies, Hudson's Bay Company (North America's oldest commercial corporation) and the North West Company, along with American companies (American Fur Company and the Pacific Fur Company), dominated the fur trade in the U.S. and Canada. The Russian-American Company controlled the trade in the North Pacific. As the large fur-trading companies moved westward from the northeast, establishing themselves in St. Louis, Missouri, they-and westward-moving colonists-required and therefore influenced intricate maritime and land transportation networks along waterways. The Missouri River connected St. Louis with the foothills of the Rocky Mountains, creating a "natural riverine highway to the west from the Mississippi" (Corbin and Rodgers 2008, p. 7) that became a vector for trade, migration, and the establishment of extractive industries in the region. A maritime archaeological study of early steamboat development and the subsequent 19th-century expansion of the upper Missouri West (Fig. 5) centered on an analysis of the wreck of the steamboat Red Cloud, which struck a snag and sank en route to Fort Benton in July 1882 and drew attention to the ways that inland waterways were instrumental during Manifest 


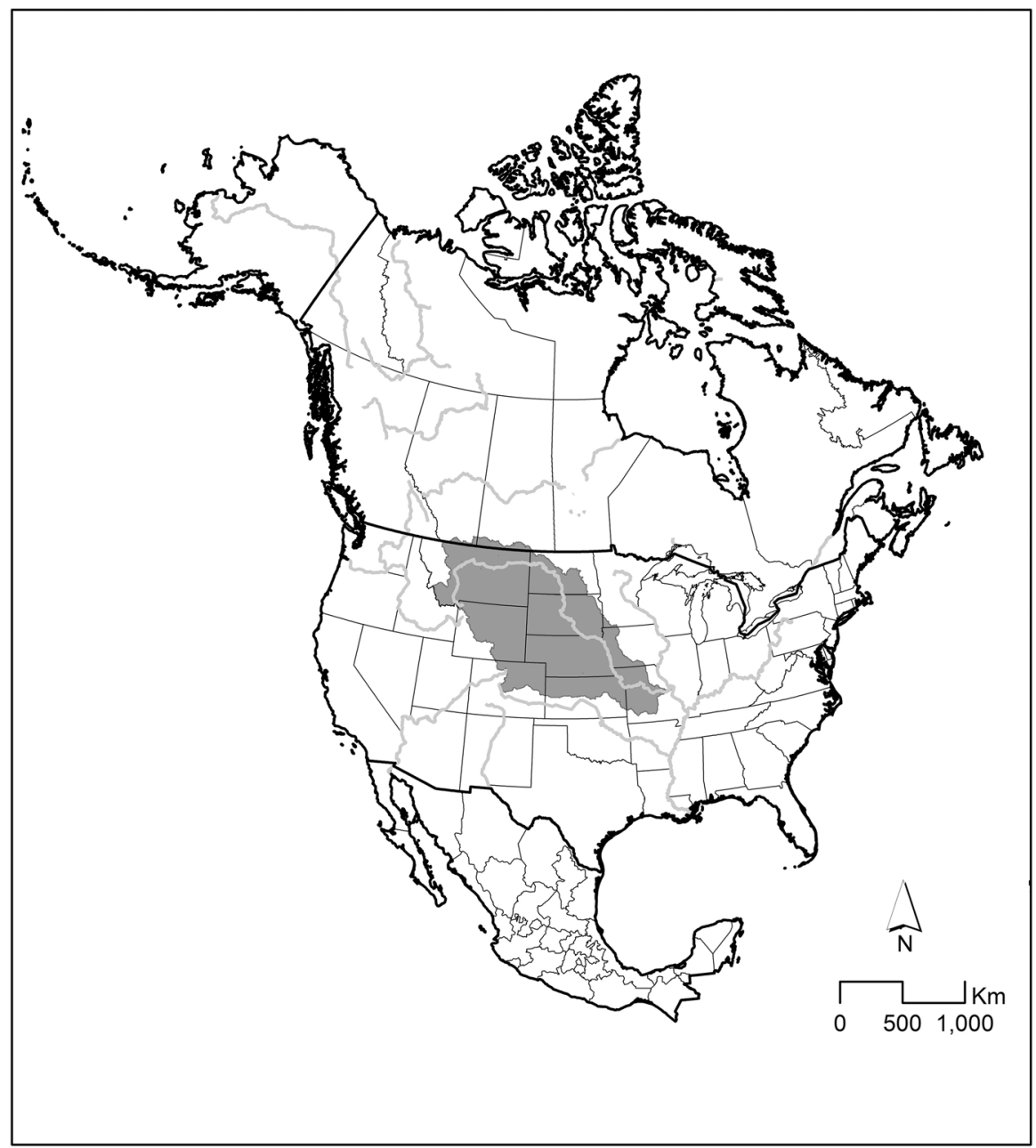

Fig. 5 Map showing the Missouri River Watershed. The inland waterways facilitated westward migration, with Manifest Destiny and settlement connecting the upper Missouri West continent (map courtesy of Diane Whited)

Destiny's mid-19th-century (1845-1849) context of westward migration (Corbin 2006).

Archaeological studies of the fur trade during this era have often focused on outposts referred to as "forts." Forts of the American West included fortresses established by fur trading companies, but "fort" also was used to describe military posts and private enterprises. Thus, the term "fort" was applied to the hundreds of military forts, presidios, and trading posts established throughout the American West (Frazer 1965). Archaeologists have conducted research at presidios (e.g., Barker et al. 1995; Blind et al. 2004) and military forts (e.g., Mueller 2011; Staski and Reiter 1996; Woodward 1958). Given the transnational connections of these 
outposts - along with relationships between with local, indigenous cultures-the fur-trade-era archaeological research can help us understand "modern world system" interconnections between relatively remote outposts and the rest of the world (Burley et al. 1996; Hamilton 2002; Pfeiffer 1981, 1982, 2006; Sudbury 2009; see also Wallerstein 1974, 1980) and is producing data that are ripe for studies in ethnogenesis and social organization (Burley 1989, 2000; Burley et al. 1992, 1996; Carlson 2006; Ewen 1986; Hamilton 2002; Lightfoot 2005; Pyszczyk 1985, 1989). Many of these investigations illustrate the ways that colonialism, landscape transformation, migration, and industrial capitalism (labor) overlap.

For example, Russian merchants along the Pacific Coast intensely harvested terrestrial and marine mammals and exploited indigenous peoples to procure and process furs and to work as porters and manual laborers; unlike the missionaries, who interacted with California Indians to transform values and cultures, the Russian merchants interacted with them in order to exploit them as cheap labor (Lightfoot 2005, p. 7; see also Silliman 2004). The success of the Russian-American Company in Alaska (an estimated 50,000 fur seals were killed each year between 1798 and 1821) was based on the "unsurpassed" hunting skills of Aleut labor (Veltre and McCartney 2002, p. 11). Similarly, the Iñupiat Eskimos of the western Arctic became an essential labor force for commercial whalers, representing an example of the global expansion of European American industrial capitalism and its increasing needs for more labor and raw materials. Nevertheless, the Iñupiat capitalized on the system, introducing a newfound material wealth that "did not destroy the fabric of Iñupiat life" and representing an excellent example of social adaptation (Cassell 2005, pp. 148-149).

Mining ventures represent another extractive industry undergoing extensive archaeological analysis in the West. Spanish "explorers and settlers searched for the mythical El Dorado" as soon as they ran aground in the region, developing mineral and metal mines in the American Southwest and southern California and introducing mining technologies developed in medieval Europe (Hardesty 2010, p. xiii; see also Van Bueren 2004). The lure of mining brought mass migrations of people, planned impermanence, and extreme landscape changes (Brand 2012; Hardesty 2010; Spude et al. 2011).

Mining rushes are considered episodes of colonization because they "involve the establishment of colonies or groups of people in places distant from their homeland and previously unknown to them," and each rush left behind a distinctive material expression of the colonization events (Hardesty 2003, p. 82). Examples of these mining-based colonization events range from studies related to the history of mining technology to the social and cultural histories of mining communities and their social and physical environments (Dixon 2005; James 1998, 2012; Hardesty 1991a, b, 1994, 1998a, b, 2001, 2003, 2007, 2010, 2011a; Mills 2011; Mills and Spude 2011; Quivik 2000, 2003, 2007; Spude et al. 2011; Timmons and Dixon 2014; West 1979; White 2003, 2006).

In 1848, the discovery of gold at Sutter's Fort, Coloma, California, became the first of a series of global mining rushes in the American West, with mining communities springing up along the Fraser River in British Columbia and Pike's Peak, Colorado, in the 1850s and in Nevada's famous Comstock Mining District 
during the 1860s and 1870s (Hardesty 2010; Lawrence 2005). During the latter portion of the 19th century, mining rushes persisted throughout the West, with archaeological investigations documenting and understanding the complexities of these extractive ventures, including examples from such places as the Cariboo region of British Columbia (Chen 2001); Bannack, Alder Gulch, and the Garnet Range of Montana (Mathews n.d.; Timmons 2007); Leadville and Cripple Creek, Colorado (Sweitz 2012); Idaho's Clearwater Basin (Rice 1977); and the Black Hills of South Dakota (Fosha and Leatherman 2008). By the late 19th century and into the early 20th century, the Klondike Gold Rush became the new "Eldorado" (Spude and Mills 2011, p. 1). Additional 20th-century mining booms took place at various locations throughout the American West, with communities like Butte, Montana, becoming the focus of historical studies that are in need of archaeology (Emmons 1990; Finn 2012; Glasscock 1935; Malone 1981).

Although "longer-term historic interactions between Native Americans and the mining industry [have] largely evaded scholarly attention" (White 2006, p. 5), research related to the impacts of mining on indigenous populations, much like archaeologies of labor, cut across the multifaceted milieu of colonialism, industrial capitalism, and landscape transformations in the American West. Hattori's (1975, 1998) ethnohistorical and archaeological analyses "shifted the register" to view Nevada's Comstock Mining District's rapid urbanization and mining landscape development from the vantage of the northern Paiutes. As with other extractive industries, mining on the Comstock was destructive to the traditional economy of the indigenous residents. "Faced with displacement from their homeland and almost certain starvation, some northern Paiute Indians modified their traditional lifestyles and created a distinctive, urban ethnic group within Virginia City's [Nevada] cosmopolitan population" (Hattori 1998, p. 229).

Recent studies related to cultural resource management of mining resources in Alaska are "creating narratives that are both more inclusive and [that] provide a more accurate continuity with today's First Nations and Alaska Native communities" (Purser 2011, pp. 77-78). For example, by integrating Chilkoot and Chilkat Tlingits coped with the swift transformations brought about by 19th- and early 20thcentury mining, as their hunting and fishing grounds and coastal-inland trade routes were usurped by the Klondike Gold Rush (Thornton 2011, p. 95; see also King 2011; Mills and Spude 2011, p. 92).

Mining communities in the West included families, bachelor communities, and all-female households, all of which navigated intersections of culture, class, and gender-based identity on a daily basis. They are laboratories for social or technical or "sociotechnical" archaeological questions (Hardesty 2003, 2010, 2011a). They also have provided springboards for studying archaeologies of labor (see also Camp 2011b; Silliman 2001, 2006, p. 156; Wolf 1982, p. 75) and collective action such as the prolific research emerging from the archaeological sites at Colorado's Berwind coal camp and Ludlow tent colony, both of which were related to the infamous 1913-1914 labor strike in southern Colorado coal fields (Ludlow Collective 2001; McGuire 2008; McGuire and Reckner 2002; Saitta 2007a, b; Walker 2003; Walker and Saitta 2002; Wood 2004). 
Other archaeological analyses of industrial capitalism in the West explicitly highlight the role of men and women - and masculinity and femininity - as the center of their inquiry (Hardesty 1998a; Higgs and Sattler 2011, p. 305; Spude 2005, pp. 89-91, 2006, pp. 309-310, 2011; Thurlo 2010, p. 90; Timmons 2007; see also Lawrence 1998). Archaeological studies of prostitution, a social and economic institution of the 19th-century American city (Seifert 2005, p. 1), serve as reminders of boomtown entrepreneurs capitalizing on the bachelor communities associated with extractive industrial communities (Meyer et al. 2005; Purser 1991; Spude 2005). Given the prevalence of the American West's bachelor communities and the relative dearth of masculinity research in anthropologies of gender (Gutmann 1997), studies of masculinity are integral to understanding the nuances of gender roles in communities associated with military activities, extractive industries, and other pursuits in the region, including fraternities (Wilkie 2010).

Gender roles were among the social networks being created and recreated in the West's communities associated with extraction industries. These networks were strengthened by the advent of relatively rapid innovations in communication. While not technically an extractive industry, communication was necessary for industrial capitalism. The iconic nature of the Pony Express, its role in connecting the American West to the rest of the world, and the potential for communication sites have been the subject of archaeological inquiry, with a focus on two stations in central Nevada that were subsequently used as telegraph stations after the Pony Express went out of existence (Hardesty 1978, 1979). These communication and transportation systems were integral to larger ideological processes transforming perceived "wilderness" into perceived "civilization" (Blanchard 2010, pp. 2-3). Electronic communications during the 19th and 20th centuries profoundly affected the development of the modern world, connecting isolated communities in the American West with the rest of the nation and the far reaches of the globe. The transcontinental telegraph was completed in 1861, effectively shutting down the Pony Express and allowing extremely rapid transmission of information and connection to an international market (Blanchard 2010; Hardesty 2010, pp. 176, 184).

The Pony Express route and telegraph stations often used stagecoach routes and stations, a reminder that communication and transportation were interconnected. In terms of transportation, roads and trails can be interpreted as material expressions of regional connections that span economic, political, and social relationships and boundaries (Purser 1989, 1992; see also Brooks and Prine 1996). Rivers provided another means of access into the region. While it had once been part of a "frontier" to the eastern states, the Mississippi, by the late 19th century, had become the center of the country. The Missouri River connected St. Louis with the foothills of the Rocky Mountains, creating a "natural riverine highway to the west from the Mississippi" that hosted a bustling steamboat industry which connected "frontier" settlements along the Missouri River with the goldfields in California and the Rocky Mountains (Corbin and Rodgers 2008, pp. 7, 113-114).

By the 1880s, railroads replaced steamboats as the driving force of America's transcontinental expansion. Transcontinental railroads were essential to the nation's growing information and transportation networks, connecting financial and political 
interests with the West's resources and urban centers and carrying natural resources from the American West to factories in the eastern U.S. They also conveyed information and lavish goods (e.g., oysters chilled in refrigerated cars) from coasts to remote communities in the interior of western North America. Archaeologies of railroad construction camps are providing fodder for more educated ways of considering the impacts of diasporas, landscape transformation, and industrial capitalism on railroad construction and use (Kraus 1975; Lake 1994; Landreth and Condon 1985; Merritt et al. 2012; Rossillon 1984; Wegars 1991).

Eventually, the automobile became the catalyst for additional changes to the American West's communication and transportation networks (e.g., Monaghan 2002). Dedicated in 1913 for the automobile, the Lincoln Highway was first "highway" across the West, connecting New York City's Times Square with Lincoln Park, San Francisco. Pristine segments of this Lincoln Highway still exist and have been documented as part of National Register of Historic Places evaluations (Dixon 1996). Another thoroughfare, Route 66, which connected Chicago with Los Angeles, has become the most internationally famous highway in the American West (Lamb 2012). The hotels, souvenir shops, cafes, and other commercial forms of Americana represent the most recent, visible heritage along the Route 66 landscape. The Society for Commercial Archaeology has worked to preserve the kitsch cultural heritage of Route 66 and other places associated with the recent transportation and tourist history of the American West. Beyond Route 66 but within the context of this modern, pop heritage of the West, archaeologists are also studying subjects like the cultural landscape of Las Vegas and its uncanny appeal to popular culture (Holtorf 2005) and the archaeology of temporary gatherings, such as Burning Man (White 2013).

Transportation corridors and technological innovations also created opportunities for tourism. Historical archaeological studies of tourist sites represents a relatively new field of study (Corbin and Russell 2010) but one with astounding potential, given the historical significance of tourist destinations, including national parks and monuments in the West. These large tracts of conserved land signify areas that have ecological significance because they have been protected from transformations brought about by extractive industries and other development. Yellowstone was the first national park in the world, established March 1, 1872; now 126 countries use this as a model to protect ecosystems (Locke and Deardon 2005).

\section{A postcolonial, industrial, transnational, and transformed region: Discussion and directions for future research}

As a whole, historical archaeological investigations are demonstrating a variety of ways in which the recent, global colonization of the American West has heralded rapid cultural and environmental transformations and has fueled "processes of conquest and conflict over political borders, resources, land ownership, and people" (Heilen and Reid 2009, p. 147). There is much that can collectively be learned from these examples to help us understand and adapt to the modern cultural successors of issues that include ethnogenesis, landscape ethics, law, and postcolonial coping (Dalglish 2012; Hardesty 1999, 2007; Little 2009; McKoy 2002-2003; Rockman 
and Flatman 2012). Archaeological inquiries related to the past few centuries have implicated colonialism as a trigger for land degradation caused by "unintended...unexpected, and relatively sudden" (Hill et al. 2009, p. 256) changes associated with the "...disruption of traditional practices" (Fisher et al. 2009b, p. 10; see also Butler 2004; Fisher 2004; O’Connor 2004) taking place over the past several centuries in the American West.

Colonizers, as a rule, implemented Western scientific knowledge "to the exclusion of indigenous knowledge, yet failed to locate a sustainable balance between consumptive uses and conservation of natural resources" (Ross and Pickering 2002, p. 196). Significant historical archaeological contributions will be those that strike a balance between cultural and natural resource management and that integrate tribal collaborations, traditional ecological knowledge, and colonial histories in order to present lessons and case studies focused on issues such as adaptation, resilience, and sustainability in the American West (e.g., Bowser and Zedeño 2009; Carter et al. 2005; Cassell 2005; Fawcett and Lewelling 2000; Fowler 2000; Lightfoot 2005; Mason et al. 2012; McDonald et al. 1991; Nevers and Rucks 2011; Stoffle et al. 2001; Weisiger 2004; Zedeño 2007). There also are models to follow by looking at advances in Australian cultural heritage, where responsibilities for and decisions about land and resources management are being returned to traditional owners so that indigenous people are "equal partners in land management decision making" (Brockwell et al. 2013; Ross and Pickering 2002; see also Australian Institute for Aboriginal and Torres Strait Islander Studies 2000; Burke and Smith 2010; Guilfoyle et al. 2009; Patterson 1993).

Collaborations with descendant communities have demonstrated the ways in which scientific and historical data can be integrated with traditional ways of the indigenous people using and managing the North American environment. Despite this potential, historical archaeology's "material culture paradigm... has often given short shrift to the environment" (Mrozowski 2010, p. 123). While not all research in the American West is outwardly dedicated to studying the historical contingency of environmental issues, the conceptual themes around which I organized this article indicate that historical archaeology in the region demonstrates the ways in which sociocultural and environmental matters are inherently connected. I argue that the future of historical archaeology in the West will be grounded in research that integrates the themes outlined herein and transcends the nature-culture divide. Such research will establish the relevance of archaeologies of the recent past to assist with modern-world decisions and inevitable global changes. Because archaeologists are in a "privileged position to understand and make sense of the impact of [issues such as] climate change on human populations" (Mitchell 2008, p. 1095), historical archaeological research that emphasizes the integrated socionatural spectrum of topics in the West, including aridity, adaptation, vast landscape transformation, and sustainability, will certainly have a "place in the archaeology of the future" (Mrozowski 2006, p. 23, 2010, p. 123; see also Fisher et al. 2009a; Hardesty 2007).

Taking into account the importance of archaeology's power to provide relevant data for the future, and considering the aridity of most environments in the West, archaeological analyses of water issues represent a vital direction for future research in the region. Western historians and the region's archaeologists and anthropologists 
are clearly aware of the significance of the region's aridity and have been so for decades (Church 2002; Clark 2011; Fiege 1999; Grayson 1993; Hardesty 2007; Hardesty and Fowler 2001; Malone 1989; Steward 1955; White 2006; Worster 1992). The American West's vast stretches of arid land have long influenced anthropological and historical interpretations of prehistoric and historic cultures in the region. Ideological and practical means of coping with aridity need to be considered a core feature of the region's culture; they also need to be integrated with other themes, including colonialism, ethnogenesis, urbanization, urban ecosystems, industrialization, Victorianism, and agency (Brooks and Prine 1996, pp. 87-88, 94; Grimm et al. 2008; Hardesty 1980, 1991a, p. 3).

The deserts of the Southwest and Northwest Mexico are dealing with a whole other set of problems related to cultural influences and water use in "resort cities," as there continue to be obvious concerns over scarce water supplies supporting places like Las Vegas (Moehring 1989; Reisner 1986; Solomon 2010; Wilds 2010). Clearly, archaeologies of water rights, use, and sustainability are relevant to guide planning and decision-making as the West's water sagas-and "water wars"evolve (Brady 2009; Cederberg 2012; Montana PBS 2012; see also Butte-Silver Bow Public Works 2012). Indeed, many of the archaeological studies examined here underscore the significance of water in some manner, even if water was not necessarily the focus of the research (Barker et al. 1995; Church 2002, 2008; Clark 2011; Crawford 2005; Fee 1993; Fowler 1950; Hardesty 1980, 1991a, b, 2010; James 2012; Laumbach et al. 2001; Mallea-Olaetxe 2000; Reynolds 1995, 1996; Stoffle et al. 2001; Van Bueren et al. 1999; White 2006). In addition, there also are archaeological studies related to the lives of worker villages associated with the construction of dams during the West's period of dam building to harness the region's great rivers (Maniery 2002; Rogge et al. 1995; Van Bueren 2002).

These archaeological investigations of water use underscore the ways that human behavior has sparked relatively sudden extreme cultural and environmental transformations in the West. Related archaeological resources represent a bridge to better understanding the impact of the world's most recent mass colonization by providing a foundation for considering "contemporary human activities, as well as the historic sweep of past environmental change" in the archaeologies of a region where it is possible to still observe and document the phases of such changes (Fisher et al. 2009b, p. 3), and where it is still feasible to include the memories of descendant communities in archaeological inquiry (González-Tennant 2011; King 2011; Orser 2010, p. 134; Voss 2005, pp. 434-435; Voss and Allen 2008; Yang and Hellman 1998; but see McGhee 2008; Silliman 2010).

Research that addresses such anthropogenic influences on the landscape has become increasingly significant to other fields, particularly since the natural sciences are now seeking insights from the social sciences to better address the "new environmentalism" of the 21st century (Watts 2007). Historical archaeologies in the American West have the potential to change consciousness and direct action (cf. Barnes 2011, p. 3; see also McGuire 2008, p. 14), particularly as the region continues to experience human dilemmas related to balancing resource extraction with sustainable conservation-especially in arid areas (Flores 2001). Research related to understanding such topics as past cultural responses to climate change, 
industrial capitalism, landscape transformations, and colonialism can be "instructive for assessing modern societal preparedness for a changing and uncertain future" (deMenocal 2001, p. 672).

Given the American West's vast cultural and natural landscapes, the region's archaeology is poised to make significant contributions toward the complex environmental transformations, human-environment interactions, and relevant landscape lessons from the past few centuries, possessing the "power to make people think about key issues in new ways" (Sabloff 2008, p. 51). As "the insanity of doing nothing becomes increasingly obvious" (Kolbert 2012) amid "humanity's greatest environmental crisis" (Tainter 2000, pp. 331-332), the current generation of archaeologists has an obligation to take action by plotting a course of responsible stewardship and sustainability. Historical archaeologies in the American West are highlighting the ramifications of the swift cultural and environmental changes that are still affecting western North America and have already begun to make contributions that will help us navigate the challenges associated with the modern world.

Acknowledgments My sincere gratitude goes to Gary Feinman, Linda Nicholas, and the Journal of Archaeological Research's editorial staff; reviewers Rebecca Allen and Ron James; five anonymous reviewers; an Institute on Ecosystems award from the NSF EPSCoR Program, Track-1 EPS-1101342 (INSTEP 3); and the National Park Service's American Battlefield Protection Program (GA-2255-11024). I am grateful to C. Riley Augé for her work with Historical Archaeology's online database; to Ma'chellee Allison for editorial assistance with the first of many bibliographies; to Diane Whited for producing the maps; and especially to Giles $\mathrm{C}$. Thelen for taking the time to review a series of drafts and to assist with bibliographic revisions. Finally, it is essential to acknowledge the thriving cadre of students and colleagues working with the University of Montana's Department of Anthropology, which is where much of the inspiration for this paper was forged.

Open Access This article is distributed under the terms of the Creative Commons Attribution License which permits any use, distribution, and reproduction in any medium, provided the original author(s) and the source are credited.

\section{References cited}

Alanen, A. R. (2000). Midwesterners in the Mantuska Valley: Colonizing rural Alaska during the 1930s. Perspectives in Vernacular Architecture 8: 53-80.

Allen, R. (1998). Native Americans at Mission Santa Cruz, 1791-1834: Interpreting the Archaeological Record, Perspectives in California Archaeology 5, Institute of Archaeology, University of California, Los Angeles.

Allen, R. (2010a). Rethinking mission land use and the archaeological record in California: An example from Santa Clara. Historical Archaeology 44(2): 72-96.

Allen, R. (2010b). Alta California missions and the pre-1849 transformation of coastal lands. Historical Archaeology 44(3): 69-80.

Allen, R., Huddleson, J. E., Wooten, K. J., and Farris, G. J. (eds.) (2013). Ceramic Identification in Historical Archaeology: The View from California, University of Nebraska Press and Society for Historical Archaeology, Norman.

Ambler, M., Little Bear, R. E., Wilson, D., Tall Bull, L., Hantz, J., Ward, C., and Wertman, B. (2008). We, the Northern Cheyenne: Our Land, Our History, Our Culture, Chief Dull Knife College, Lame Deer, MT. 
Anschuetz, K. F., Wilshusen, R. H., and Scheick, C. L. (2001). An archaeology of landscapes: Perspectives and directions. Journal of Archaeological Research 9: 157-211.

Arkush, B. S. (2011). Native responses to European intrusion: Cultural persistence and agency among mission neophytes in Spanish colonial northern California. Historical Archaeology 45(4): 62-90.

Arnold, J. B., II, and Keyes, S. J. (2000). Remembering the "Queen City of the West": The untapped archaeological resources of Indianola, Texas. International Journal of Historical Archaeology 4: 335-348.

Australian Institute for Aboriginal and Torres Strait Islander Studies (2000). Guidelines for Ethical Research in Indigenous Studies (http://www.aiatsis.gov.au/research/docs/ethics.pdf).

Ayres, J. E. (ed.) (1995). The Archaeology of Spanish and Mexican Colonialism in the American Southwest, Society for Historical Archaeology, Ann Arbor, MI.

Ballard, H. (2004). The cultural landscape approach: A methodological case study from Hite's Cove, California, a hard-rock gold mining site. Paper presented at the 37th Annual Meeting of the Society for Historical and Underwater Archaeology, St. Louis, MO.

Barker, L. R., Allen, R., and Costello, J. G. (1995). The archaeology of Spanish and Mexican Alta California. In Ayres, J. E. (ed.), The Archaeology of Spanish and Mexican Colonialism in the American Southwest, Society for Historical Archaeology, Ann Arbor, MI, pp. 3-51.

Barnes, J. A. (2011). Introduction: The materiality of freedom-archaeologies of postemancipation life. In Barnes, J. A. (ed.), The Materiality of Freedom: Archaeologies of Post-Emancipation Life, University of South Carolina Press, Columbia, pp. 1-25.

Basso, K. H. (1996). Wisdom Sits in Places: Landscape and Language Among the Western Apache, University of New Mexico Press, Albuquerque.

Baxter, R. S. (2002). Industrial and domestic landscapes of a California oil field. Historical Archaeology 36(3): $18-27$.

Baxter, R. S. (2008). The response of California's Chinese populations to the anti-Chinese movement. Historical Archaeology 42(3): 29-36.

Baxter, R. S., and Allen, R. A. (2005). Mining the West. In De Cunzo, L., and Jameson, J. H. (eds.), Unlocking the Past: Celebrating Historical Archaeology in North America, Society for Historical Archaeology and the University Press of Florida, Gainesville. (http://www.sha.org/ unlockingthepast/changing_environments/baxter_allen.htm).

Baxter, R. S., and Allen, R. (2008). National Register of Historic Places evaluation and damage assessment for CA-PLA-2002/H (summit camp). Report prepared for Tahoe National Forest, Truckee Ranger District, Truckee, CA.

Bayman, J. M. (2009). Technological change and the archaeology of emergent colonialism in the kingdom of Hawai'i. International Journal of Historical Archaeology 13: 127-157.

Beaudry, M. C. (2011). Stitching women's lives: Interpreting the artifacts of sewing and needlework. In Beaudry, M. C., and Symonds, J. (eds.), Interpreting the Early Modern World, Springer, London.

Beck, W. A., and Haase, Y. D. (1989). Historical Atlas of the American West, University of Oklahoma Press, Norman.

Bertando, L. (1997). Mission San Antonio de Padua archaeological field school excavations of 1993, 1994, and 1996. Pacific Coast Archaeological Society Quarterly 33: 57-93.

Billington, M. L., and Hardaway, R. D. (eds.) (1998). African Americans on the Western Frontier, University Press of Colorado, Niwot.

Black, L. T. (2004). Russians in Alaska: 1732-1867, University of Alaska Press, Fairbanks.

Blackhawk, N. (2006). Violence Over the Land: Indians and Empires in the Early American West, Harvard University Press, Cambridge, MA.

Blanchard, M. (2010). Wires, Wireless and Wilderness: A Sociotechnical Interpretation of Three Military Communication Stations on the Washington Alaska Military Cable and Telegraph System (WAMCATS), Ph.D. dissertation, Department of Anthropology, University of Nevada, Reno.

Blee, C. H. (1985). Archeological Investigations at the Russian Bishop's House, 1981, Sitka National Historical Park, Sitka, Alaska, U.S. Government Printing Office, Denver.

Blee, C. H. (1989). Siberian goats and North American deer: A contextual approach to the translation of Russian common names for Alaskan mammals. Arctic 42(3): 227-231.

Blee, C. H. (1990). The archeology of a Russian hospital trash pit. In Pierce, R. (ed.), Proceedings of the Second International Russian American Conference, Sitka, Alaska, University of Alaska Press, Fairbanks.

Blee, C. H., Musitelli, M., Scott, L. J., Aasen, D. K. and Chomko, S. A. (1986). Wine, Yaman and Stone: The Archeology of a Russian Hospital Trash Pit, Sitka National Historical Park, Sitka, Alaska, U.S. Government Printing Office, Washington, DC. 
Blind, E. B., Voss, B. L., Osborn, S. K., and Barker, L. R. (2004). El Presidio de San Francisco: At the edge of empire. Historical Archaeology 38(3): 135-149.

Bowser, B. J., and Zedeño, M. N. (eds.) (2009). The Archaeology of Meaningful Places, University of Utah Press, Salt Lake City.

Brady, J. (2009). Water wars out West: Keep what catch! National Public Radio, June 1, 2009. (http:// www.npr.org/templates/story/story.php?storyId=104643521).

Brand, M. (2012). Living at the edge of a boomtown: Transient life in Dawson City during the Klondike gold rush. In Spude, C. H., Mills, R. O., Gurcke, K., and Sprague, R. (eds.), Eldorado! The Archaeology of Gold Mining in the Far North, University of Nebraska Press, Lincoln, pp. 203-220.

Brockwell, S., O'Connor, S., and Byrne, D. (eds.) (2013). Transcending the Culture-Nature Divide in Cultural Heritage: Views from the Asia-Pacific, Australian National University, Canberra.

Brooks, A., and Jacon, S. (1993). Homesteading and Agricultural Development Context, South Dakota Historical Preservation Center, Vermillion.

Brooks, A., and Prine, E. (1996). Historical archaeology in the American west: Examples from South Dakota and Nevada. World Archaeology Bulletin 7: 87-96.

Brooks, J. F. (2002). Captives and Cousins: Slavery, Kinship, and Community in the Southwest Borderlands, University of North Carolina Press, Chapel Hill.

Brooks, J., DeCorse, C. R., and Walton, J. (eds.) (2008). Small Worlds: Twelve Studies in Microhistory, School of Advanced Research Press, Santa Fe, NM.

Brown, K. (2000). Ghost towns tell tales of ecological boom and bust. Science 290: 35-37.

Brugge, D. M. (1985). Navajos in the Catholic Church Records of New Mexico, 1694-1875, Navajo Community College Press, Tsaile, AZ.

Buck, D. (1994). When is a trail an emigrant trail? From Verdi to Dog Valley: A Truckee-Donner route revision. Report to the Tahoe National Forest Supervisor's Office, Nevada City, CA.

Buechler, J. (1990). Homesteads: Assessing the archaeological significance. Paper presented at the Northwestern Plains Archaeological Symposium, Billings, MT.

Burke, H., and Smith, C. (2010). Vestiges of colonialism: Manifestations of the culture/nature divide in Australian heritage management. In Messenger, P. M., and Smith, G. S. (eds.), Cultural Heritage Management: A Global Perspective, University Press of Florida, Gainesville, pp. 21-37.

Burley, D. V. (1989). Function, meaning, and context: Ambiguities in ceramic use by the Hivernant Metís of the northwestern Plains. Historical Archaeology 23(1): 97-106.

Burley, D. V. (2000). Creolization and late nineteenth century Métis vernacular log architecture on the South Saskatchewan River. Historical Archaeology 34(3): 27-35.

Burley, D. V., Horsfall, G. A., and Brandon, J. D. (1992). Structural Considerations of Metís Ethnicity: An Archaeological, Architectural, and Historical Study, University of South Dakota, Vermillion.

Burley, D. V., Hamilton, J. S., and Fladmark, K. R. (1996). Prophecy of the Swan: The Upper Peace River Fur Trade of 1794-1823, University of British Columbia Press, Vancouver.

Butler, V. (2004). Where have all the native fish gone? The fate of fish that Lewis and Clark encountered on the lower Columbia River. Oregon Historical Quarterly 105: 438-463.

Butte-Silver Bow Public Works (2012). Butte-Silver Bow Public Works presentation to the Butte-Silver Bow Natural Resource Damage Restoration Council, February 2012, Butte, Montana. Meeting minutes on file, Butte-Silver Bow Courthouse, Butte, MT.

Butzer, K., and Butzer, E. (2000). Domestic architecture in early colonial Mexico: Material culture as (sub)text. In Murphy, A., and Johnson, D. (eds.), Cultural Encounters with the Environment, Rowman and Littlefield, Lanham, MD, pp. 17-37.

Byrd, B. F., Allen, R., and Baxter, R. S. (2012). Archaeological investigations for Phase I of the Sunnydale Sewer System Improvement Project, case No. 2009.0311E. Report prepared for the San Francisco Planning Department. Ms. on file, Far Western Anthropological Research Group, Davis, CA.

Camp, S. L. (2011a). Consuming citizenship? The archaeology of Mexican immigrant ambivalence in early twentieth-century Los Angeles. International Journal of Historical Archaeology 15: 305-328.

Camp, S. L. (2011b). Materializing inequality: The archaeology of tourism laborers in turn-of-the-century Los Angeles. International Journal of Historical Archaeology 15: 279-297.

Captain, G. (1995). Social, religious, and leisure pursuits of northern California's African American population: The discovery of gold through World War II. Masters thesis, Department of History, University of California, Berkeley. 
Carlson, C. C. (2006). Indigenous historic archaeology of the 19th-century Secwepemc Village at Thompson's River Post, Kamloops, British Columbia. Canadian Journal of Archaeology 30: 193-250.

Carter, T., Chappell, E., and McCleary, T. (2005). In the lodge of the chickadee: Architecture and cultural resistance on the Crow Indian Reservation, 1884-1920. Perspectives in Vernacular Architecture 10: 97-111.

Cassell, M. S. (2005). The landscape of Iñupiat Eskimo industrial labor. Historical Archaeology 39(3): $132-151$.

Cederberg, J. (2012). Carlyle corporate website targets 'archetypical' left-wing environmentalist Montanan. Missoulian, June 1.

Chen, Y. (2001). In the Colonies of Tang: Historical Archaeology of Chinese Communities in the North Caribou District, British Columbia, Ph.D. dissertation, Department of Department of Archaeology, Simon Fraser University, Vancouver, British Columbia.

Chicone, S. (2011a). Respectable rags: Working-class poverty and the 1913-14 southern Colorado coal strike. International Journal of Historical Archaeology 15: 51-81.

Chicone, S. (2011b). From goats to gardens: Feeding southern Colorado's working-class poor. Historical Archaeology 45: 121-139.

Chung, S. F. (1998). Their changing world: Chinese women on the Comstock, 1860-1910. In James, R. M., and Raymond, C. E. (eds.), Comstock Women: The Making of a Mining Community, University of Nevada Press, Reno, pp. 203-228.

Chung, S. F., and Wegars, P. (eds.) (2005). Chinese American Death Rituals: Respecting the Ancestors, AltaMira, Lanham, MD.

Church, M. C. (2002). The grant and the grid: Homestead landscapes in the late nineteenth-century borderlands of southern Colorado. Journal of Social Archaeology 2: 220-244.

Church, M. C. (2008). Purgatorio, purgatoire, or picketwire: Negotiating local, national, and transnational identities along the Purgatoire River in nineteenth-century Colorado. In Scheiber, L. L., and Clark, B. J. (eds.), Archaeological Landscapes on the High Plains, University Press of Colorado, Boulder, pp. 173-202.

Church, M. C., Baker, S. G., Clark, B. J., Carillo, R. F., Horn, J. C., Späth, C. D., Guilfoyle, D. R., and Cassells, E. S., with contributions by Corbett, K., Smith, D. A., Sullenberger-Fry, M., and Neely, B. (2007). Colorado History: A Context for Historical Archaeology, Colorado Council of Professional Archaeologists, Denver.

Clark, B. J. (2005). Lived ethnicity: Archaeology and identity in Mexicano America. World Archaeology 37: 440-452.

Clark, B. J. (2011). On the Edge of Purgatory: An Archaeology of Place in Hispanic Colorado, University of Nebraska Press and the Society for Historical Archaeology, Lincoln.

Clayton, C., Hoy, J., and Underwood, J. (2001). Vaqueros, Cowboys, and Buckaroos, University of Texas Press, Austin.

Connolly, T. J., Ruiz, C. L., McLaughlin, J., Tasa, G. L., and Kallenbach, E. (2010). The archaeology of a pioneer family cemetery in western Oregon, 1854-1879. Historical Archaeology 44(4): 28-45.

Cooper, D. C., and Spude, C. H. (2011). Tobacco pipes, medicinals, and decorated dishes: The archaeology of gender, economic class in households form Skagway, Alaska. In Spude, C. H., Mills, R. O., Gurcke, K., and Sprague, R. (eds.), Eldorado! The Archaeology of Gold Mining in the Far North, University of Nebraska Press, Lincoln, pp. 109-125.

Corbin, A. (2006). The Life and Times of the Steamboat Red Cloud, or How Merchants, Mounties, and the Missouri Transformed the West, Texas A\&M University Press, College Station.

Corbin, A., and Rodgers, B. A. (2008). The Steamboat Montana and the Opening of the West, University Press of Florida, Gainesville.

Corbin, A., and Russell, M. A. (2010). Historical Archaeology of Tourism in Yellowstone National Park, Society for Historical Archaeology and Springer, New York.

Cordell, L. S., and Fowler, D. D. (eds.) (2005). The Uncertain Foundations of Southwestern Mission Archaeology in Current Views on the American Southwest, University of Utah Press, Salt Lake City.

Costello, J. G., Hallaran, K., Warren, K., and Akin, M. (2008). The luck of Third Street: Archaeology of Chinatown, San Bernadino, California. Historical Archaeology 42(3): 136-151.

Cox, B. R. (2007). The Archaeology of the Allensworth Hotel: Negotiating the system in Jim Crow America. African Diaspora Archaeology Newsletter, September. Electronic document. (www. diaspora.uiuc.edu/news0907/news0907.html\#6, accessed June 5, 2012). 
Crawford, K. (2005). In the sheep: Aspen carvings as indicators of land capacity and use. Society for California Archaeology Newsletter 39: 26-29.

Crosby, A. W. (1994). Germs, Seeds, and Animals: Studies in Ecological History, M. E. Sharpe, Armonk, NY.

Crosby, A. W. (2005). Ecological Imperialism: The Biological Expansion of Europe, 900-1900, 2nd ed., Cambridge University Press, Cambridge, UK.

Dalglish, C. (2012). Archaeology and landscape ethics. World Archaeology 44: 327-341.

Deetz, J. F. (1977). In Small Things Forgotten: An Archaeology of Early American Life, Doubleday, New York.

Delgado, J. P. (2009). Gold Rush Port: The Maritime Archaeology of San Francisco's Waterfront, University of California Press, Berkeley.

deMenocal, P. B. (2001). Cultural responses to climate change during the late Holocene. Science 292: $667-673$.

Dixon, K. J. (1996). Heritage resource inventory of the Crystal Fire Rehabilitation Project (historic site NRHP evaluations), Report No. TY-94-1059 Toiyabe National Forest; Report No. 05-17-1125 Tahoe National Forest, Tahoe National Forest Supervisor's Office, Nevada City, CA.

Dixon, K. J. (2005). Boomtown Saloons: Archaeology and History in Virginia City, Nevada, University of Nevada Press, Reno.

Dixon, K. J. (2006). Sidling up to the archaeology of western saloons: Historical archaeology takes on the wild of the West. World Archaeology 38: 576-585.

Dixon, K. J. (2011). "A place of recreation of our own": Archaeology of the Boston Saloon. In Barnes, J. A. (ed.), The Materiality of Freedom: Archaeologies of Post-Emancipation Life, University of South Carolina Press, Columbia, pp. 115-135.

Dixon, K. J., and McQueen, R. W., with contributions by Aranyosi, E. F., and Leeman, H. W. (1997). Heritage resource report for the Cottonwood Fire Rehabilitation Project. Tahoe National Forest Report 05-171131, Part II: Historical Resources, Tahoe National Forest Supervisor's Office, Nevada City, CA.

Dixon, K. J., Novak, S. A., Schug, G. R., Schablitsky, J. M., Scott, G. R., and Tasa, G. L. (2010). "Men, women, and children starving": Archaeology of the Donner family camp. American Antiquity 75: 627-656.

Dixon, K. J., Schablitsky, J. M., and Novak, S. A. (eds.) (2011). An Archaeology of Desperation: Exploring the Donner Party's Alder Creek Camp, University of Oklahoma Press, Norman.

Emmons, D. M. (1990). The Butte Irish: Class and Ethnicity in an American Mining Town, 1875-1925, University of Illinois Press, Urbana.

Ewen, C. R. (1986). Fur trade archaeology: A study of frontier hierarchies. Historical Archaeology 20(1): $15-28$.

Farnsworth, P. (1989). Native American acculturation in the Spanish colonial empire: The Franciscan missions of Alta California. In Champion, T. C. (ed.), Center and Periphery: Comparative Studies in Archaeology, Unwin Hyman, London, pp. 186-206.

Fawcett, W. B., and Lewelling, W. R. (2000). Lemuel's Garden: Confronting issues of race, class and power through the differential preservation of archaeological sites in northern Utah. In Delle, J. A., Mrozowski, S., and Paynter, R. (eds.), Lines that Divide: Historical Archaeologies of Race, Class, and Gender, University of Tennessee Press, Knoxville, pp. 40-57.

Fee, J. (1993). Idaho's Chinese mountain gardens. In Wegars, P. W. (ed.), Hidden Heritage, Historical Archaeology of the Overseas Chinese, Baywood, Amityville, NY, pp. 65-96.

Fennell, C. (2011). Early African America: Archaeological studies of significance and diversity. Journal of Archaeological Research 19: 1-49.

Fiege, M. (1999). Irrigated Eden: The Making of an Agricultural Landscape in the American West, University of Washington Press, Seattle.

Finn, J. L. (2012). Mining Childhood: Growing Up in Butte, 1900-1960, Montana Historical Society Press, Helena.

Fischer, J. R. (2007). Cattle in Hawai'i: Biological and cultural exchange. Pacific Historical Review 76: 347-372.

Fisher, A. H. (2004). Tangled nets: Treaty rights and tribal identities at Celilo Falls. Oregon Historical Quarterly 105: 178-211.

Fisher, C. T., Hill, J. B., and Feinman, G. M. (eds.) (2009a). The Archaeology of Environmental Change: Socionatural Legacies of Degradation and Resilience, University of Arizona Press, Tucson.

Fisher, C. T., Hill, J. B., and Feinman, G. M. (2009b). Introduction: Environmental studies for twentyfirst-century conservation. In Fisher, C. T., Hill, J. B., and Feinman, G. M. (eds.), The Archaeology 
of Environmental Change: Socionatural Legacies of Degradation and Resilience. University of Arizona Press, Tucson, pp. 1-12.

Fitzsimons, G. (1996). Uncivil engineers: The struggle for control of Seattle's early water and electric utilities, 1890-1910. Industrial Archeology 22(1): 11-34.

Flexner, J. L. (2012). An institution that was a village: Archaeology and social life in the Hansen's Disease settlement at Kalawawo, Moloka'i, Hawai'i. International Journal of Historical Archaeology 16: 135-163.

Flores, D. (2001). The Natural West: Environmental History in the Great Plains and Rocky Mountains, University of Oklahoma Press, Norman.

Fosha, R. E., and Leatherman, C. (2008). The Chinese experience in Deadwood, South Dakota. Historical Archaeology 42(3): 97-110.

Fowler, C. S. (2000). "We live by them": Native knowledge of biodiversity in the Great Basin of western North America. In Minnis, P. E., and Elisens, W. J. (eds.), Biodiversity in Native North America, University of Oklahoma Press, Norman, pp. 99-132.

Fowler, H. D. (1950). Camels to California: A Chapter in Western Transportation, Stanford University Press, Stanford, CA.

Fox, R. A., Jr. (1993). Archaeology, History, and Custer's Last Battle, University of Oklahoma Press, Norman.

Fox, R. A., Jr., and Scott, D. D. (1991). The post-Civil War battlefield pattern: An example from the Custer battlefield. Historical Archaeology 25(2): 92-103.

Frazer, R. W. (1965). Forts of the West: Military Forts and Presidios and Posts Commonly Called Forts West of the Mississippi River to 1898, University of Oklahoma Press, Norman.

Frazier, I. (1989). Great Plains, Farrar, Strauss, Giroux, New York.

Fritz, H. W. (2004). The Lewis and Clark Expedition, Greenwood Press, Westport, CT.

Gamble, L. H., and Zepeda, I. C. (2003). Social differentiation and exchange among the Kumeyaay Indians during the historic period in California. Historical Archaeology 36(2): 71-91.

George, W. E. (2008). Lost Architecture of the Rio Grande Borderlands, Texas A\&M University Press, College Station.

Glasscock, C. B. (1935). The War of the Copper Kings: Builders of Butte and Wolves of Wall Street, Gosset and Dunlap, New York.

González-Tennant, E. (2011). Creating a diasporic archaeology of Chinese migration: Tentative steps across four continents. International Journal of Historical Archaeology 15: 509-532.

Goodyear, D. (2006). What happened at Alder Creek? Excavating the Donner Party. New Yorker 24(April 2006): 140-151.

Gosden, C. (2004). Archaeology and Colonialism: Cultural Contact from 5000 BC to the Present, Cambridge University Press, Cambridge.

Grayson, D. K. (1990). Donner Party deaths: A demographic assessment. Journal of Anthropological Research 46: 223-242.

Grayson, D. K. (1993). The Desert's Past: A Natural History of the Great Basin, Smithsonian Institution Press, Washington, DC.

Greene, J. A., and Scott, D. D. (2004). Finding Sand Creek: History, Archeology, and the 1864 Massacre, University of Oklahoma Press, Norman.

Greenwood, R. S. (1978). The Overseas Chinese at home: Life in a nineteenth-century Chinatown in California. Archaeology 31(4): 73-86.

Greenwood, R. S. (1996). Down by the Station: Los Angeles Chinatown, 1880-1933, Monumenta Archaeologica 18, Institute of Archaeology, University of California, Los Angeles.

Greenwood, R. S., and Slawson, D. N. (2008). Gathering insights on isolation. Historical Archaeology 42(3): 68-79.

Griffin, E., and Gurcke, K. (2011). An overview of Chilkoot Trail archaeology. In Spude, C. H., Mills, R. O., Gurcke, K., and Sprague, R. (eds.), Eldorado! The Archaeology of Gold Mining in the Far North, University of Nebraska Press, Lincoln, pp. 145-163.

Grimm, N. B., Grove, J. M., Pickett, S. T., and Redman, C. L. (2008). Integrated approaches to long-term studies of urban ecological systems. In Marzluff, J. M., Shulenberger, E., Endlicher, W., Alberti, M., Bradley, G., Ryan, C., Simon, U., and Zumbrunnen, C. (eds.), Urban Ecology: An International Perspective on the Interaction Between Humans and Nature, Springer, London, pp. 123-141.

Guenther, T. (1988). At home on the range: Black settlement in rural Wyoming, 1850-1950. Masters thesis, Department of Anthropology, University of Wyoming, Laramie. 
Guilfoyle, D., Bennell, B., Webb, W., Gillies, V., and Strickland, J. (2009). Integrating natural resource management and indigenous cultural heritage: A model case study from south-western Australia. Heritage Management 2: 149-176.

Gutiérrez, R. A. (1991). When Jesus Came the Corn Mothers Went Away: Marriage, Sexuality, and Power in New Mexico, 1500-1846, Stanford University Press, Stanford, CA.

Gutmann, M. C. (1997). Trafficking in men: The anthropology of masculinity. Annual Review of Anthropology 26: 385-409.

Guy, D. J., and Sheridan, T. E. (eds.) (1998). Contested Ground: Comparative Frontiers on the Northern and Southern Edges of the Spanish Empire, University of Arizona Press, Tucson.

Haines, F. (1938). The northward spread of horses among the Plains Indians. American Anthropologist 40: 429-437.

Haley, B., and Wilcoxon, L. R. (2005). How Spaniards became Chumash, and other tales of ethnogenesis. American Anthropologist 107: 432-445.

Hall, D. S., Babcock, W. A., Knudsen, S. L., Lockman, J. R., Philip, N. L., Higgins, F. R., Morrow, N. R., and Eckerle, W. (2003). Travelers Rest National Historic Landmark: Validation and verification of a Lewis and Clark campsite. Report prepared for Missoula County Office of Planning and Grants, Missoula, MT.

Hall, M., and Silliman, S. W. (2006). Introduction: Archaeology of the modern world. In Hall, M., and Silliman, S. W. (eds.), Historical Archaeology, Blackwell, Malden, MA, pp. 1-19.

Hall, T. D. (1989). Social Changes in the Southwest, 1350-1880, University Press of Kansas, Lawrence.

Hall, T. D. (2009). Puzzles in the comparative study of frontiers: Problems, some solutions, and methodological implications. Journal of World-Systems Research 15: 25-47.

Hämäläinen, P. (2003). The rise and fall of Plains Indians horse cultures. Journal of American History 90: 833-862.

Hämäläinen, P. (2008). The Comanche Empire, Yale University Press, New Haven, CT.

Hamilton, S. (2002). Dynamics of social complexity in early nineteenth-century British fur-trade posts. International Journal of Historical Archaeology 4: 217-273.

Hammer, T. J. (2011). Canyon City: The archaeology of a company town on the transportation network to the Klondike. In Spude, C. H., Mills, R. O., Gurcke, K., and Sprague, R. (eds.), Eldorado! The Archaeology of Gold Mining in the Far North, University of Nebraska Press, Lincoln, pp. 164-181.

Hanks, C. C., and Pokotylo, D. L. (1989). The Mackenzie Basin: An alternative approach to Dene and Metís archaeology. Arctic 2: 139-147.

Hardesty, D. L. (1978). Historical and archaeological investigations of the Rock Creek stage and telegraph station. Ms. on file, Bureau of Land Management, Reno, NV.

Hardesty, D. L. (1979). The Pony Express in central Nevada: Archaeological and documentary perspectives. Ms. on file, Bureau of Land Management, Reno, NV.

Hardesty, D. L. (1980). Historic sites archaeology on the western American frontier: Theoretical perspectives and research problems. North American Archaeologist 2: 67-82.

Hardesty, D. L. (1985). Evolution on the industrial frontier. In Green, S. W., and Perlman, S. M. (eds.), The Archaeology of Frontiers and Boundaries, Academic Press, New York, pp. 213-219.

Hardesty, D. L. (1991a). Historical archaeology in the American West. Historical Archaeology 25(3): 3-6.

Hardesty, D. L. (1991b). Toward an historical archaeology of the Intermountain West. Historical Archaeology 25(3): 29-35.

Hardesty, D. L. (1994). Class, gender, and material culture in the mining West. In Scott, E. M. (ed.), Those of Little Note: Gender, Race, and Class in Historical Archaeology, University of Arizona Press, Tucson, pp. 129-145.

Hardesty, D. L. (1997). Archaeology of the Donner Party, University of Nevada, Reno.

Hardesty, D. L. (1998a). Gender and archaeology on the Comstock. In James, R. M., and Raymond, C. E. (eds.), Comstock Women: The Making of a Mining Community, University of Nevada Press, Reno, pp. 283-302.

Hardesty, D. L. (1998b). Power and the industrial mining community in the American West. In Knapp, A. B., Pigott, V. C., and Herbert, E. W. (eds.), Social Approaches to an Industrial Past: The Archaeology and Anthropology of Mining, Routledge, London, pp. 81-96.

Hardesty, D. L. (1999). Historical archaeology in the next millennium: A forum. Historical Archaeology 32(2): 51-58.

Hardesty, D. L. (2001). Issues in preserving toxic wastes at heritage sites. Public Historian 23: 19-28. 
Hardesty, D. L. (2003). Mining rushes and landscape learning in the modern world. In Rockman, M., and Steele, J. (eds.), Colonization of Unfamiliar Landscapes: The Archaeology of Adaptation, Routledge, London, pp. 81-95.

Hardesty, D. L. (2007). Perspectives on global-change archaeology. American Anthropologist 109: 1-7.

Hardesty, D. L. (2010). Mining Archaeology in the American West: A View from the Silver State. University of Nebraska Press, Lincoln.

Hardesty, D. L. (2011a). Theoretical perspectives on the Frontier Mining Pattern. In Spude, C. H., Mills, R. O., Gurcke, K., and Sprague, R. (eds.), Eldorado! The Archaeology of Gold Mining in the Far North, University of Nebraska Press, Lincoln, pp. 25-33.

Hardesty, D. L. (2011b). Historical perspectives on the archaeology of the Donner party. In Dixon, K. J., Schablitsky, J. M., and Novak, S. A. (eds.), An Archaeology of Desperation: Exploring the Donner Party's Alder Creek Camp, University of Oklahoma Press, Norman, pp. 89-100.

Hardesty, D. L., and Buhr. L. (2001). Evaluating the National Register eligibility of cultural resources in the Newlands Project, Nevada. Report prepared for the US Department of the Interior, Bureau of Reclamation, Mid-Pacific Region, Sacramento, CA.

Hardesty, D. L., and Fowler, D. D. (2001). Archaeology and environmental changes. In Crumley, C. L. (ed.) with van Deventer, A. E., and Fletcher, J. L., New Directions in Anthropology and Environment: Intersections, AltaMira Press, Walnut Creek, CA, pp. 72-89.

Hattori, E. M. (1975). Northern Paiutes on the Comstock: Archaeology and Ethnohistory of an American Indian Population in Virginia City, Nevada, Occasional Paper No. 3, Nevada State Museum, Carson City.

Hattori, E. M. (1998). And some of them swear like pirates: Acculturation of American Indian women in late nineteenth-century Virginia City. In James, R. M., and Raymond, C. E. (eds.), Comstock Women: The Making of a Mining Community, University of Nevada Press, Reno, pp. 229-245.

Haught, A. C. (2010). Home Swede home: The archaeology of Swedish cultural identity at a western homestead. Masters thesis, Department of Anthropology, University of Montana, Missoula.

Hawkins, B., and Madsen, D. (1990). Excavation of the Donner-Reed Wagons, University of Utah Press, Salt Lake City.

Hegmon, M. (2003). Setting theoretical egos aside: Issues and theory in North American archaeology. American Antiquity 68: 213-243.

Heilen, M. P., and Reid, J. J. (2009). A landscape of gambles and guts: Commodification of land on the Arizona frontier. In Bowser, B. J., and Zedeño, M. N. (eds.), The Archaeology of Meaningful Places, University of Utah Press, Salt Lake City, pp. 132-148.

Hess, J. A. (1996). Inventions and patents for the public good: The needle-valve program of the Bureau of Reclamation. Industrial Archeology 22(1): 35-49.

Higgs, A. S., and Sattler, R. A. (2011). Cabin comforts: The archaeology of bachelor cabins on Fish Creek, Alaska. In Spude, C. H., Mills, R. O., Gurcke, K., and Sprague, R. (eds.), Eldorado! The Archaeology of Gold Mining in the Far North, University of Nebraska Press, Lincoln, pp. 288-308.

Hill, J. B., Fisher, C. T., and Feinman, G. M. (2009). The socionatural connection: Closing comments. In Fisher, C. T., Hill, J. B., and Feinman, G. M. (eds.), The Archaeology of Environmental Change: Socionatural Legacies of Degradation and Resilience, University of Arizona Press, Tucson, pp. 251-258.

Hill, L. K. (1987). The historical archaeology of ethnic woodcutters in the Carson Range. Masters thesis, Department of Anthropology, University of Nevada, Reno.

Holtorf, C. (2005). From Stonehenge to Las Vegas: Archaeology as Popular Culture, AltaMira Press, Walnut Creek, CA.

Hull, K. L. (2009). Pestilence and Persistence: Yosemite Indian Demography and Culture in Colonial California, University of California Press, Berkeley.

Hunt, L. (1982). The Clover Valley Lumber Company: A study in industrial archaeology. Ms on file, U.S. Department of Agriculture, Forest Service, Plumas National Forest, Quincy, CA.

Hurtado, A. L. (1996). When strangers met: Sex and gender on three frontiers. Frontier: A Journal of Women Studies 17: 52-75.

James, R. M. (1998). The Roar and the Silence, University of Nevada Press, Las Vegas.

James, R. M. (2012). Virginia City: Secrets of a Western Past, University of Nebraska Press and the Society for Historical Archaeology, Lincoln.

James, R. M., and Raymond, C. E. (eds.) (1998). Comstock Women: The Making of a Mining Community, University of Nevada Press, Las Vegas. 
Johnson, K. (1996). “Unfortunate Emigrants”: Narratives of the Donner Party, Utah State University Press, Logan.

Johnson, S. L. (2000). Roaring Camp: The Social World of the California Gold Rush, W. W. Norton, New York.

Jordan, T. G., Kilpinen, J. T., and Gritzner, C. F. (1997). The Mountain West: Interpreting the Folk Landscape, Johns Hopkins University Press, Baltimore, MD.

Kamp-Whittaker, A. (2010). Through the eyes of a child: The archaeology of WWII Japanese American Internment camp at Amache. Masters thesis, Department of Anthropology, University of Denver, Denver.

Karsmizki, K. W. (2004). Cartographic representations: A controversy in mapping Lewis and Clark's Fort Clatsop. Oregon Historical Quarterly 105: 568-587.

Karuzas, E. L. (2008). Retracing Lolo Trail. We Proceeded On 34: 21-25.

Katz, W. L. (1996). The Black West: A Documentary and Pictorial History of the African American Role in Westward Expansion of the United States, Simon and Schuster, New York.

King, R. E. (2011). Alaska natives in the gold rush: A look at Valdez Creek in the early- to mid-19th century. In Spude, C. H., Mills, R. O., Gurcke, K., and Sprague, R. (eds.), Eldorado! The Archaeology of Gold Mining in the Far North, University of Nebraska Press, Lincoln, pp. 274-287.

Kolbert, E. (2012). The big heat. New Yorker, July 23, 2012 (http://www.newyorker.com/talk/comment/ 2012/07/23/120723taco_talk_kolbert).

Kraus, G. (1975). Chinese laborers and the construction of the Central Pacific. Utah Historical Quarterly 37: 41-57.

Kraus-Friedberg, C. (2008). Transnational identity and mortuary material culture: The Chinese plantation cemetery in Pāhala, Hawai'i. Historical Archaeology 42(3): 123-135.

Kraus-Friedberg, C. (2011). Across the Pacific: Transnational context in the Japanese plantation workers' cemetery in Pāhala, Hawai'i. International Journal of Historical Archaeology 15: 381-408.

Kroll, A. J. (2012). The center of a homesteading community in northwest Montana: Archaeological investigations on the Polebridge Schoolhouse. Masters thesis, Department of Anthropology, University of Montana, Missoula.

Kulisheck, J. (2003). Pueblo population movements, abandonment and settlement change in sixteenth and seventeenth-century New Mexico. The Kiva 69: 30-54.

Lake, H. (1994). Construction of the CPRR: Chinese immigrant contribution. Northeastern Nevada Historical Society Quarterly 94: 188-199.

Lamb, D. (2012). The mystique of Route 66. Smithsonian 12(1): 38-45 (http://www.smithsonianmag. com/travel/The-Mystique-of-Route-66.html).

Landreth, K. B., and Condon, M. (1985). Archaeological investigations at the Cabinet Landing site (10BR413), Bonner County, Idaho. Report No.100-45, Reports in Archaeology and History, Eastern Washington University, Cheney, WA.

Lang, W. L. (1998). Helena, Montana's black community, 1900-1912. In Billington, M. E., and Hardaway, R. D. (eds.), African Americans on the Western Frontier, University Press of Colorado, Niwot, pp. 198-216.

Laumbach, K. W. (2001). Fire fight at Hembrillo Basin. Archaeology 54: 34-39.

Laumbach, K. W., with contributions by Hart, R. L., Scott, D. D., and Wakeman, J. (2001). Hembrillo, An Apache battlefield of the Victorio War: The Archaeology and History of the Hembrillo Battlefield, Human Systems Research Report No. 9730, White Sands Missile Range, Tularosa, NM.

Lawrence, S. (1998). Gender and community structure on Australian colonial goldfields. In Knapp, A. B., Pigott, V. C., and Herbert, E. W. (eds.), Social Approaches to an Industrial Past: The Archaeology and Anthropology of Mining, Routledge, London, pp. 39-58.

Lawrence, S. (2005). Colonisation in the industrial age: The landscape of the Australian gold rush. In Casella, E., and Symonds, J. (eds.), Industrial Archeology: Future Directions, Kluwer Academic/ Plenum Press, New York, pp. 279-300.

Layton, T. (2002). Gifts from the Celestial Kingdom: A Shipwrecked Cargo for Gold Rush California, Stanford University Press, Palo Alto, CA.

Lazarus, E. (1991). Black Hills/White Justice: The Sioux Nation versus the United States, 1775 to the Present, HarperCollins, New York.

Lee, B., Brenner, A., and Monks, G. G. (2002). Detecting economic variability in the Red River settlement. Historical Archaeology 36(2): 18-49. 
Leone, M. P. (1973). Archeology as the science of technology: Mormon town plans and fences. In Redman, C. (ed.), Research and Theory in Current Archeology, Wiley, New York, pp. $125-150$.

Leone, M. P. (1995). A historical archaeology of capitalism. American Anthropologist 97: 251-268.

Liebmann, M. (2006). "Burn the Churches, Break up the Bells": The Archaeology of the Pueblo Revolt Revitalization Movement in New Mexico, AD 1680-1686, Ph.D. dissertation, Department of Anthropology, University of Pennsylvania, Philadelphia.

Liebmann, M. (2008). Introduction: The intersections of archaeology and postcolonial studies. In Liebmann, M., and Rizvi, U. Z. (eds.), Archaeology and the Postcolonial Critique, AltaMira, Lanham, MD, pp. 1-20.

Lightfoot, K. G. (1995). Culture contact studies: Redefining the relationship between prehistoric and historical archaeology. American Antiquity 60: 99-217.

Lightfoot, K. G. (2005). Indians, Missionaries, and Merchants: The Legacy of Colonial Encounters on the California Frontiers, University of California Press, Berkeley.

Lightfoot, K. G. (2006). Mission, gold, furs, and Manifest Destiny: Rethinking an archaeology of colonialism for western North America. In Hall, M., and Silliman, S. W. (eds.), Historical Archaeology, Blackwell, Malden, MA, pp. 272-292.

Lightfoot, K. G., and Martinez, A. (1995). Frontiers and boundaries in archaeological perspective. Annual Review of Anthropology 24: 471-492.

Limerick, P. N. (1987). The Legacy of Conquest: The Unbroken Past of the American West, W.W. Norton, New York.

Limerick, P. N. (1991). The trail to Santa Fe: The unleashing of the Western public intellectual. In Limerick, P. N., Milner II, C. A., and Rankin, C. E. (eds.), Trails: Towards a New Western History, University Press of Kansas, Lawrence, pp. 59-77.

Lindström, S. (1993). Archaeological evaluation and data recovery at Ca-NEV-572-H: A Chinese cabin site at Juniper Flat, Cambridge Estates subdivision, Truckee, California. Report prepared for CRB Development, Fair Oaks, CA.

Lindström, S., Waechter, S., Rucks, M., Reno, R., and Zeier, C. (2007). From Ice Age to ice works: Archaeological, ethnohistorical, and historical studies for the Truckee River Legacy Trail Project (phase 3). Forest Service Report TNF01806/R2007051700011, Tahoe National Forest, Truckee Ranger District, Truckee, CA.

Lingenfelter, R. E. (1986). Death Valley and the Amargosa: A Land of Illusion, University of California Press, Berkeley.

Little, B. J. (1994). People with history: An update on historical archaeology in the United States. Journal of Archaeological Method and Theory 1: 5-40.

Little, B. J. (2009). What can archaeology do for justice, peace, community, and the earth? Historical Archaeology 43(4): 115-119.

Locke, H., and Deardon, P. (2005). Rethinking protected areas and the new paradigm. Environmental Conservation 32(1): 1-10.

Ludlow Collective (2001). Archaeology of the Colorado Coal Field War, 1913-1914. In Buchli, V., and Lucas, G. (eds.), Archaeologies of the Contemporary Past, Routledge, London, pp. 94-107.

Madsen, B. D. (1985). The Shoshone Frontier and the Bear River Massacre, University of Utah Press, Salt Lake City.

Makley, M. S., and Makley, M. J. (2010). Cave Rock: Climbers, Courts, and a Washoe Sacred Space, University of Nevada Press, Reno.

Mallea-Olaetxe, J. (2000). Speaking Through the Aspens: Basque Tree Carvings in California and Nevada, University of Nevada Press, Reno.

Mallios, S. (2009). Scientific excavations at Palomar Mountain's Nate Harrison Site: The historical archaeology of a legendary African-American pioneer. The Journal of San Diego History 55: $141-160$.

Mallios, S., and Caterino, D. M. (2007). Transformations in San Diego County gravestones and cemeteries. Historical Archaeology 41(4): 50-71.

Mallios, S., and Caterino, D. (2011). Mortality, money, and commemoration: Social and economic factors in southern California grave-marker change during the 19th and 20th centuries. International Journal of Historical Archaeology 3: 429-460.

Malone, M. (1981). The Battle for Butte: Mining and Politics on the Northern Frontier, University of Washington Press, Seattle. 
Malone, M. (1989). Beyond the last frontier: Toward a new approach to western American history. Western Historical Quarterly 20: 409-419.

Maniery, M. L. (2002). Health, sanitation, and diet in a twentieth-century dam construction camp: A view from Butt Valley, California. Historical Archaeology 36(3): 69-84.

Mason, L., White, G., Morishima, G., Alvarado, E., Andrew, L., Clark, F., Durglo, M., Sr., Durglo, J., Eneas, J., Erickson, J., Friedlander, M., Hamel, K., Hardy, C., Harwood, T., Haven, F., Isaac, E., James, L., Kenning, R., Leighton, A., Pierre, P., Raish, C., Shaw, B., Smallsalmon, S., Stearns, V., Teasley, H., Weingart, M., and Wilder, S. (2012). Listening and learning from traditional knowledge and Western science: A dialogue on contemporary challenges of forest health and wildfire. Journal of Forestry June: 187-193.

Matero, F. M. (2012). Field praxis report, Western Clay Manufacturing Co., Helena, Montana, 24-LC789. Report to Archie Bray Foundation and the Montana Preservation Alliance, Helena.

Mathews, A. (n.d.). History of Garnet ghost town. Bureau of Land Management, Missoula Field Office, Missoula, MT.

McDonald, J. D., Zimmerman, L. J., McDonald, A. L., Tall Bull, W., and Sun, T. R. (1991). The Northern Cheyenne outbreak of 1879: Using oral history and archaeology as tools of resistance. In McGuire, R. H., and Paynter, R. (eds.), The Archaeology of Inequality, Basil Blackwell, Oxford, pp. 64-78.

McGhee, R. (2008). Aboriginalism and the problem of indigenous archaeology. American Antiquity 73: 579-597.

McGuire, R. H. (2008). Archaeology as Political Action, University of California Press, Berkeley.

McGuire, R. H., and Reckner, P. (2002). The unromantic West: Labor, capital, and struggle. Historical Archaeology 36(3): 44-58.

McKoy, P. I. (2002-2003). The land must hold the people: Native modes of territoriality and contemporary tribal justifications for placing land into trust through 25 C.F.R. Part 151. American Indian Law Review 27(2): 421-502.

McLeod, C. M. (1984). Culture history of the Lolo Trail. Masters thesis, Department of Anthropology, University of Montana, Missoula.

McNiven, I., and Russell, L. (2005). Appropriated Pasts: Indigenous Peoples and the Colonial Culture of Archaeology, AltaMira Press, Lanham, MD.

Medicine Crow, J. (2003). Counting Coup: Becoming a Crow Chief on the Reservation and Beyond, National Geographic Society, Washington, DC.

Meinig, D. W. (1998). The Shaping of America: A Geographical Perspective on 500 Years of History, Volume 3: Transcontinental America, 1850-1915, Yale University Press, New Haven, CT.

Melville, E. K. (1994). A Plague of Sheep: Environmental Consequences of the Conquest of Mexico, Cambridge University Press, Cambridge.

Mensing, S., and Byrne, R. (1998). Pre-mission invasion of Erodium cicutarium in California. Journal of Biogeography 25: 757-762.

Meredith, S. (2007). Identifying the African American Resources Project. Montana: The Magazine of Western History 57: 61-66, 96.

Merritt, C. W. (2006). Trade and consumption in the Mormon Great Basin, 1847-1900: Locally produced ceramics and instrumental activation analysis. Masters thesis, Department of Social Sciences, Michigan Technological University, Houghton.

Merritt, C. W. (2010a). Summary of archaeological work at Rosebud Battlefield State Park. Letter report submitted to Montana State Parks, a Division of Fish, Wildlife, and Parks, Helena.

Merritt, C. W. (2011). "The Coming Man from Canton”: Chinese Experience in Montana (1862-1943), Ph.D. dissertation, Department of Anthropology, University of Montana, Missoula.

Merritt, C. W., Weisz, G., and Dixon, K. J. (2012). "Verily the road was built with Chinaman's bones": An archaeology of Chinese line camps in Montana. International Journal of Historical Archaeology 16: $666-695$.

Merritt, C. W., Milter, T., and Dixon, K. J. (2013). Archeological investigations of the Rosebud Battlefield (24BH2461), southeastern Montana. Report to the National Park Service, American Battlefield Protection Program (ABPP), for Grant GA-2255-11-024, Washington, DC.

Merritt, D. (2010b). Fort Owen. Masters thesis, Department of Anthropology, University of Montana, Missoula.

Meyer, M. D., Gibson, E. S., and Costello, J. G. (2005). City of angels, city of sin: Archaeology in the Los Angeles red-light district ca. 1900. Historical Archaeology 39(1): 107-125.

Michaels, G. (2005). Peck-marked vessels from the San José Market Street Chinatown: A study of distribution and significance. International Journal of Historical Archaeology 9: 123-134. 
Mills, P. R. (1996). A new view of Kaua'i as "The Separate Kingdom” after 1810. Hawaiian Journal of History 30: 91-104.

Mills, P. R. (2002). Hawai'i's Russian Adventure: A New Look at Old History, University of Hawai'i Press, Honolulu.

Mills, P. R. (2008). European exploration and colonization of the Hawaiian Islands. In McManamon, F. P., Cordell, L. S., Lightfoot, K. G., and Milner, G. R. (eds.), Archaeology in America, Vol. 4, Greenwood Press, Westport, CT, pp. 131-134.

Mills, P. R. (2009). Folk housing in the middle of the Pacific: Lime architecture, cultural power and ideology in 19th-century Hawaii. In White, C. (ed.), Materiality of Individuality, Springer, New York, pp. 75-91.

Mills, P. R., and Martinez, A. (eds.) (1997). The Archaeology of Russian Colonialism in the North and Tropical Pacific, Kroeber Anthropological Society Papers, No. 81, Berkeley, CA.

Mills, R. O. (2011). A proposed model for a placer gold mining settlement system. In Spude, C. H., Mills, R. O., Gurcke, K., and Sprague, R. (eds.), Eldorado! The Archaeology of Gold Mining in the Far North, University of Nebraska Press, Lincoln, pp. 34-39.

Mills, R. O., and Spude, C. H. (2011). Intermediate coastal transfer and supply settlements: Supplying the Upper Yukon through Skagway and Dyea. In Spude, C. H., Mills, R. O., Gurcke, K., and Sprague, R. (eds.), Eldorado! The Archaeology of Gold Mining in the Far North, University of Nebraska Press, Lincoln, pp. 89-93.

Milter, T. (2013). History and archaeology of the Rosebud Battlefield, June 17, 1876. Masters thesis, Department of Anthropology, University of Montana, Missoula.

Mitchell, P. (2008). Practicing archaeology at a time of climate catastrophe. Antiquity 83: 1092-1103.

Moehring, E. P. (1989). Resort City in the Sunbelt: Las Vegas, 1930-2000, University of Nevada Press, Reno.

Monaghan, D. W. (2002). Canada's "New Main Street": The Trans-Canada Highway as Ideal and Reality, 1912-1956, Canada Science and Technology Museum, Ottawa.

Montana PBS (2012). Fort Peck Dam, Montana Public Broadcasting System, KUSM-TV, Bozeman.

Morgan, D. L. (1963). Overland in 1846: Diaries and Letters of the Oregon-California Trail, Vols. 1-2, Talisman Press, Georgetown, CA.

Moss, M. L. (2005). Rifts in the theoretical landscape of archaeology in the United States: A comment on Hegmon and Watkins. American Antiquity 70: 581-587.

Mrozowski, S. A. (2006). Environments of history: Biological dimensions of historical archaeology. In Hall, M., and Silliman, S. W. (eds.), Historical Archaeology, Wiley-Blackwell, Oxford, pp. $23-41$.

Mrozowski, S. A. (2010). New and forgotten paradigms: The environment and economics in historical archaeology as anthropology. Historical Archaeology 44(3): 117-127.

Mueller, J. C. (2011). Individual agency and military structure: Personal artifacts from 1890s Fort Missoula. Masters thesis, University of Montana, Missoula.

Mullins, P. R. (1999). Race and Affluence: An Archaeology of African America and Consumer Culture, Kluwer Academic/Plenum, New York.

Mullins, P. R. (2008a). "The strange and unusual”: Material and social dimensions of Chinese identity. Historical Archaeology 42(3): 152-157.

Mullins, P. R. (2008b). Excavating America's metaphor: Diaspora and vindicationist archaeologies. Historical Archaeology 42(2): 104-122.

Murphy, M. M. (1997). Mining Cultures: Men, Women, and Leisure in Butte, 1914-1941, University of Illinois Press, Urbana.

Murray, T. (2011). Archaeologists and indigenous people: A maturing relationship? Annual Review of Anthropology 40: 363-378.

National Park Service (2012). Sand Creek Massacre National Historic Site (http://www.nps.gov/sand/ index.htm).

Neihardt, J.G. (1979). Black Elk Speaks, University of Nebraska Press, Lincoln.

Nevers, J., and Rucks, P., with contributions by Hicks, L., James, S., and Rakow, M. (2011). Under watchful eyes: Washoe narratives of the Donner Party. In Dixon, K. J., Schablitsky, J. M., and Novak, S. A. (eds.), An Archaeology of Desperation: Exploring the Donner Party's Alder Creek Camp, University of Oklahoma Press, Norman, pp. 255-290.

Nicholas, G., and Hollowell, J. (2007). Ethical challenges to a postcolonial legacy of scientific colonialism. In Hamilakas, Y., and Duke, P. (eds.), Archaeology and Capitalism: From Ethics to Politics, Left Coast Press, Walnut Creek, CA, pp. 59-82. 
Nighthorse Campbell, B. (2005). Why preserve a massacre site? So the dead may rest. In Gulliford, A. (ed.), Preserving Western History, University of New Mexico Press, Albuquerque, pp. 189-191.

Noble, B., and Spude, R. (1992). Guidelines for identifying, evaluating, registering historic mining properties, National Register Bulletin 42, National Park Service, Washington, DC.

Norman, W. T. (2012). Tradewinds and traditions: Exploring the archaeology of German Gulch. Masters thesis, Department of Anthropology, University of Montana, Missoula.

Novak, S. A. (2008). House of Mourning: A Biocultural History of the Mountain Meadows Massacre, University of Utah Press, Salt Lake City.

Novak, S. A., and Kopp, D. (2003). To feed a tree in Zion: Osteological analysis of the 1857 Mountain Meadows Massacre. Historical Archaeology 37(2): 85-108.

O'Connor, J. (2004). The evolving landscape of the Columbia River Gorge: Lewis and Clark and Cataclysms on the Columbia. Oregon Historical Quarterly 105: 390-421.

Oland, M., Hart, S., and Frink, L. (eds.) (2012). Decolonizing Indigenous Histories at the "Prehistoric/ Colonial" Intersection in Archaeology, University of Arizona Press, Tucson.

Old Coyote, H., and Old Coyote, B. (2003). The Way of the Warrior: Stories of the Crow People, University of Nebraska Press, Lincoln.

Orser, C. E., Jr. (1996). A Historical Archaeology of the Modern World, Plenum, New York.

Orser, C. E., Jr. (1999). The challenge of race to American historical archaeology. American Anthropologist 100: 661-668.

Orser, C. E., Jr. (2007). Transnational diaspora and rights of heritage. In Silverman, H., and Ruggles, D. F. (eds.), Cultural Heritage and Human Rights, Springer, New York, pp. 92-105.

Orser, C. E., Jr. (2010). Twenty-first-century historical archaeology. Journal of Archaeological Research 18: $111-150$.

Orser, C. E., Jr. (2012). An archaeology of Eurocentrism. American Antiquity 77: 737-755.

Orser, C. E., Jr. (2014). A Primer on Modern World Archaeology, Eliot Werner Publications, Clinton Corners, NY.

Osborn, A. J. (1983). Ecological aspects of equestrian adaptation in aboriginal North America. American Anthropologist 85: 563-591.

Pastron, A. G., and Delgado, J. P. (1991). Archaeological investigations of a mid-19th-century shipbreaking yard, San Francisco, California. Historical Archaeology 25(3): 61-77.

Patterson, T. C. (1993). Archaeology: The Historical Development of Civilizations. 2nd ed., PrenticeHall, Englewood Cliffs, NJ.

Paullin, P. K. (2007). Boring to the core: The archaeology, history, and dendrochronology of a railroad logging camp, Ladee Flat, Clackamas County, Oregon. Masters thesis, Oregon State University, Corvallis.

Pauls, E. P. (2006). The place of space: Architecture, landscape, and social life. In Hall, M., and Silliman, S. W. (eds.), Historical Archaeology, Wiley-Blackwell, Oxford, pp. 65-83.

Pavao-Zuckerman, B., and LaMotta, V. M. (2007). Missionization and economic change in the Pimería Alta: The zooarchaeology of San Agustín de Tucson. International Journal of Historical Archaeology 11: 241-268.

Paynter, R. (2000a). Historical and anthropological archaeology: Forging alliances. Journal of Archaeological Research 8: 1-37.

Paynter, R. (2000b). Historical archaeology and the post-Columbian world of North America. Journal of Archaeological Research 8: 169-217.

Pfeiffer, M. A. (1981). Clay tobacco pipes from Spokane House and Fort Colvile. Northwest Anthropological Research Notes 15: 221-235.

Pfeiffer, M. A. (1982). Tobacco pipes and the fur trade of the Pacific Northwest and Northern Plains. Masters thesis, Department of Anthropology, University of Idaho, Moscow.

Pfeiffer, M. A. (2006). Tobacco Pipes and the Fur Trade of the Pacific Northwest and Northern Plains, Phytolith Press, Ponca City, OK.

Pomeroy, E. (2008). The American Far West in the Twentieth Century, Yale University Press, New Haven, CT.

Powers, T. (2011). The Killing of Crazy Horse, Vintage, Random House, New York.

Praetzellis, A., and Praetzellis, M. (1992a). Faces and facades: Victorian ideology in early Sacramento. In Yentsch, A. E., and Beaudry, M. C. (eds.), The Art and Mystery of Historical Archaeology, CRC Press, Boca Raton, FL, pp. 75-99. 
Praetzellis, A., and Praetzellis, M. (1992b). "We Were There, Too": Archaeology of an African-American Family in Sacramento, California, Cultural Resources Facility, Anthropological Studies Center, Sonoma State University, Rohnert Park, CA.

Praetzellis, A., and Praetzellis, M. (2001). Mangling symbols of gentility in the Wild West: Case studies in interpretive archaeology. American Anthropologist 103: 645-654.

Praetzellis, A., Praetzellis, M., and Brown, M. R. (1987). Artifacts as symbols of identity: An example from Sacramento's gold rush era Chinese community. In Staski, E. (ed.), Living in Cities: Current Research in Urban Archaeology, Special Publication No. 5, Society for Historical Archaeology, Tucson, AZ, pp. 38-48.

Pred, A. (2008). Place as historically contingent process: Structuration and the time-geography of becoming places. Annals of American Geographers 74: 279-297.

Prentiss, A. M. (2012). Field Seasons: Reflections on Career Paths and Research in American Archaeology, University of Utah Press, Salt Lake City.

Preucel, R. W. (ed.) (2002). Archaeologies of the Pueblo Revolt: Identity, Meaning, and Renewal in the Pueblo World, University of New Mexico Press, Albuquerque.

Purser, M. (1989). All roads lead to Winnemucca: Local road systems and community material culture in nineteenth-century Nevada. In Carter, T., and Herman, B. (eds.), Perspectives in Vernacular Architecture, University of Missouri Press, Columbia, pp. 120-134.

Purser, M. (1991). "Several paradise ladies are visiting in town": Gender strategies in the early industrial West. Historical Archaeology 25(4): 6-16.

Purser, M. (1992). Consumption as communication in nineteenth-century Paradise Valley, Nevada. Historical Archaeology 26(3): 105-116.

Purser, M. (2011). New perspectives from the north: Comparing opportunities and challenges in an archaeology of Eldorado. In Spude, C. H., Mills, R. O., Gurcke, K., and Sprague, R. (eds.), Eldorado! The Archaeology of Gold Mining in the Far North, University of Nebraska Press, Lincoln, pp. 76-87.

Pyszczyk, H. W. (1985). The role of material culture in the structure of fur trade society. In Thompson, M., Garcia, M. T., and Kense, F. (eds.), Status, Structure and Stratification: Current Archaeological Reconstructions, Archaeological Association, University of Calgary, Calgary, pp. 399-406.

Pyszczyk, H. W. (1989). Consumption and ethnicity: An example from the fur trade in western Canada. Journal of Anthropological Archaeology 8: 213-249.

Quivik, F. L. (2000). Landscapes as industrial artifacts: Lessons from environmental history. Industrial Archeology 26: 55-64.

Quivik, F. L. (2003). Gold and tailings: The Standard mill at Bodie, California. Industrial Archeology 26: 5-27.

Quivik, F.L. (2007). The historical significance of tailings and slag: Industrial waste as cultural resource. Industrial Archeology 33: 35-52.

Reisner, M. (1986). Cadillac Desert: The American West and its Disappearing Water, Viking Press, New York.

Reno, R. R. (1996). Fuel for the Frontier: Industrial Archeology of Charcoal Production in the Eureka Nevada Mining District, 1869-1891, Ph.D. dissertation, University of Nevada, Reno.

Reséndez, A. (2005). Changing Identities at the Frontier: Texas and New Mexico, 1800-1850, Cambridge University Press, Cambridge, MA.

Reynolds, T. S. (1995). Good engineering, poor management: The Battle Creek hydroelectric system and the demise of the Northern California Power Company. Industrial Archeology 22: 5-24.

Reynolds, T. S. (1996). Dams and hydroelectric technology in the American West: A different model. Industrial Archeology 22: 5-9.

Rice, D. G. (1977). An Archaeological Assessment of Historic Moose City, Clearwater County, Idaho, Anthropological Research Manuscript Series No. 30, University of Idaho, Moscow.

Ringhoff, M., and Stoner, E. (2011). The River and the Railroad: An Archaeological History of Reno, University of Nevada Press, Reno.

Robbins, W. G. (1991). Laying siege to Western history: The emergence of new paradigms. In Limerick, P. N., Milner II, C. A., and Rankin, C. E. (eds.), Trails: Towards a New Western History, University Press of Kansas, Lawrence, pp. 182-214.

Robbins, W. G. (1994). Colony and Empire: The Capitalist Transformation of the American West, University Press of Kansas, Lawrence.

Rockman, M., and Flatman, J. (eds.) (2012). Archaeology and Society: Its Relevance in the Modern World, Springer, London. 
Rockman, M., and Steele, J. (eds.) (2003). Colonization of Unfamiliar Landscapes: The Archaeology of Adaptation, Routledge, New York.

Rogers, C. L. (1997). Making camp Chinese style: The archaeology of a V\&T Railroad graders' camp, Carson City, Nevada. Report prepared by Archaeological Research Services for Silver Oak Development Company, Carson City, NV.

Rogers, D. J. (1993). Ku on the Columbia: Hawaiian laborers in the Pacific Northwest fur industry. Masters thesis, Oregon State University, Corvallis.

Rogge, A. E., McWatters, D. L., Keane, M., and Emanuel, R. P. (1995). Raising Arizona's Dams: Daily Life, Danger, and Discrimination in the Dam Construction Camps of Central Arizona, 1890s-1940s, University of Arizona Press, Tucson.

Rohe, R. E. (1982). After the gold rush: Chinese mining in the far West, 1850-1890. Montana: The Magazine of Western History 32: 2-19.

Rohe, R. E. (1996). Chinese river mining in the West. Montana: The Magazine of Western History 46: 14-29.

Ronda, J. P. (ed.) (1998). Voyages of Discovery: Essays on the Lewis and Clark Expedition, Montana Historical Society Press, Helena.

Ronda, J. P. (2003). Why Lewis and Clark matter. Smithsonian 34: 98-101.

Ross, A., and Pickering, K. (2002). The politics of reintegrating Australian Aboriginal and American Indian Indigenous knowledge into resource management. Human Ecology 30: 187-214.

Ross, D. E. (2011). Factors influencing the dining habits of Japanese and Chinese migrants at a British Columbia salmon cannery. Historical Archaeology 45(2): 69-96.

Rossillon, M. (1984). The Curecanti Archaeological Project: The Archaeology of Marion, an Historic Railroad Camp in Curecanti National Recreation Area, Colorado, Occasional Studies in Anthropology No. 9, Midwest Archaeological Center, National Park Service, Lincoln, NE.

Rossillon, M. (2008). Final Report of Archaeological Investigations of Butte's Chinatown. Renewable Technologies, Butte, MT.

Roth, M. W. (2000). IA and the 20th century city: Who will love the Alameda corridor? Industrial Archeology 26: 71-84.

Rothschild, N. A. (2006). Colonialism, material culture, and identity in the Rio Grande and Hudson River Valleys. International Journal of Historical Archaeology 10: 72-107.

Rusco, E. (1975)."Good Times Coming?" Black Nevadans in the Nineteenth Century, Greenwood Press, Westport, CT.

Sabloff, J. A. (2008). Archaeology Matters: Action Archaeology in the Modern World, Left Coast Press, Walnut Creek, CA.

Saitta, D. J. (2007a). Archaeology of Collective Action, University Press of Florida, Gainesville.

Saitta, D. J. (2007b). Ethics, objectivity, and emancipatory archaeology. In Hamilakis, Y., and Duke, P. (eds.), Archaeology and Capitalism, Left Coast Press, Walnut Creek, CA, pp. 267-280.

Saraceni, J. E. (1998). Searching for Lewis and Clark. Archaeology (Newsbriefs) 51(1) (http://www. archaeology.org/9801/newsbriefs/lewis.html).

Scarlett, T. J. (1999). Narcissus's mirror: Manufacture and modernism in the American Great Basin-the case of pottery. International Journal of Historical Archaeology 3: 167-175.

Scarlett, T. J. (2006). Globalizing flowscapes and the historical archaeology of the Mormon domain. International Journal of Historical Archaeology 10: 109-134.

Scarlett T. J., Speakman, R. J., and Glascock, M. D. (2007). Pottery in the Mormon economy: An historical and archaeometric study. Historical Archaeology 41(4): 70-95.

Schablitsky, J. M. (2007). Western boomtowns: The lost episodes. In Schablitsky, J. M. (ed.), Box Office Archaeology: Refining Hollywood's Portrayals of the Past, Left Coast Press, Walnut Creek, CA, pp. 179-199.

Schamberger, H. A. (1969). Historic Mining Camps of Nevada, Water Supply for the Comstock: Early History, Development, Water Supply, Nevada Department of Conservation and Natural Resources and U.S. Geological Survey, Carson City, NV.

Schrieber, L. L., and Mitchell, M. D. (eds.) (2010). Across a Great Divide: Continuity and Change in Native North American Societies, 1400-1900, University of Arizona Press, Tucson.

Schubert, F. N. (1971). Black soldiers on the white frontier: Some factors influencing race relations. Phylon 32: 410-415.

Schulz, P. D., and Allen, R. (eds.) (2008). Archaeology and architecture of the overseas Chinese: A bibliography. Historical Archaeology 42(3): 171-193. 
Scott, D. D. (1994). A Sharp Little Affair: The Archaeology of the Big Hole Battlefield, J and L Reprint Company, Lincoln, NE.

Scott, D. D. (2005). Interpreting archaeology at Little Bighorn Battlefield National Monument. In Gulliford, A. (ed.), Preserving Western History, University of New Mexico Press, Albuquerque, pp. 20-31.

Scott, D. D., and McFeaters, A. P. (2011). The archaeology of historic battlefields: A history and theoretical development in conflict archaeology. Journal of Archaeological Research 19: 103-132.

Scott, D. D., Fox, R., Jr., Connor, M. A., and Harmon, D. (1989). Archaeological Perspectives on the Battle of the Little Bighorn, University of Oklahoma Press, Norman.

Scott, D. D., Willey, P., and Connor, M. A. (1998). They Died with Custer: Soldiers' Bones from the Battle of the Little Bighorn, University of Oklahoma Press, Norman.

Seifert, D. J. (2005). Archaeology in Sin City. Historical Archaeology 39(1): 1-3.

Seymour, D. J. (2007). A syndetic approach to identification of the historic mission site of San Cayetano del Tumacácori. International Journal of Historical Archaeology 11: 269-296.

Shapiro, J. S. (2008). Before Santa Fe: Archaeology of a City Different, Museum of New Mexico Press, Santa Fe.

Shew, D. O. (2010). Feminine identity confined: The archaeology of Japanese women at Amache, a WWII internment camp. Masters thesis, University of Denver, Denver, CO.

Silliman, S. W. (2001). Theoretical perspectives on labor and colonialism: Reconsidering the California missions. Journal of Anthropological Archaeology 20: 379-407.

Silliman, S. W. (2004). Lost Laborers in Colonial California: Native Americans and the Archaeology of Rancho Petaluma, University of Arizona Press, Tucson.

Silliman, S. W. (2005). Culture contact or colonialism? Challenges in the archaeology of Native North America. American Antiquity 70: 55-74.

Silliman, S. W. (2006). Struggling with labor, working with identities. In Hall, M., and Silliman, S. W. (eds.), Historical Archaeology, Blackwell, Malden, MA, pp. 147-166.

Silliman, S. W. (2010). The value and diversity of indigenous archaeology: A response to McGee. American Antiquity 75: 217-220.

Skiles, S. A., and Clark, B. J. (2010). When the foreign is not exotic: Ceramics at Colorado's WWII Japanese internment camp. In Dillian, C. D., and White, C. L. (eds.), Trade and Exchange: Archaeological Studies from History and Prehistory, Springer, New York, pp. 179-192.

Smith, A. (2004). Fitting into a new place: Irish immigrant experiences in shaping a Canadian landscape. International Journal of Historical Archaeology 8: 217-230.

Smith, C. E., and Dixon, K. J. (2005). Determination of eligibility for inclusion in the National Register of Historic Places of 19 historic sites within the Heavenly Ski Resort, Douglas County, Nevada. Report R2004-0519-00048 prepared for U.S. Forest Service, Lake Tahoe Basin Management Unit, South Lake Tahoe and Heavenly Ski Resort, South Lake Tahoe, CA.

Smith, S. L. (2011). Remaking slavery in a free state: Masters and slaves in gold rush California. Pacific Historical Review 80: 28-63.

Solomon, S. (2010). Water: The Epic Struggle for Wealth, Power, and Civilization, HarperCollins, New York.

Sorenson, G. H. (2012). Iron Riders: The Story of the 1890s Fort Missoula Buffalo Soldier Corps, Pictorial Historic Publishing, Missoula, MT.

Spielmann, K. A., Mobley-Tanaka, J. L., and Potter, J. (2006). Style and resistance in the seventeenth century Salinas province. American Antiquity 71: 621-647.

Spielmann, K. A., Hawkey, D., Rainey, K., and Fish, S. K. (2009). “...being weary, they had rebelled”: Pueblo subsistence and labor under Spanish colonialism. Journal of Anthropological Archaeology 28: $102-125$.

Spude, C. H. (2005). Brothels and saloons: An archaeology of gender in the American West. Historical Archaeology 39(1): 89-106.

Spude, C. H. (2006). The Mascot Saloon: Archaeological Investigations in Skagway, Alaska, Vol. 10, National Park Service, U.S. Department of the Interior, Anchorage, AK.

Spude, C. H. (2011). Predicting social and economic function at residential and commercial sites types in the far north, 1880-1920. In Spude, C. H., Mills, R. O., Gurcke, K., and Sprague, R. (eds.), Eldorado! The Archaeology of Gold Mining in the Far North, University of Nebraska Press, Lincoln, pp. 50-75. 
Spude, C. H., and Mills, R. O. (2011). Rediscovering El Dorado: An introduction to this volume. In Spude, C. H., Mills, R. O., Gurcke, K., and Sprague, R. (eds.), Eldorado! The Archaeology of Gold Mining in the Far North, University of Nebraska Press, Lincoln, pp. 1-7.

Spude, C. H., Mills, R. O., Gurcke, K., and Sprague, R. (eds.) (2011). Eldorado! The Archaeology of Gold Mining in the Far North, University of Nebraska Press, Lincoln.

Stands in Timber, J., and Liberty, M. (1969). Cheyenne Memories, Yale University Press, New Haven, CT.

Starrs, P. F. (1998). Let the Cowboy Ride: Cattle Ranching in the American West, Johns Hopkins University Press, Baltimore, MD.

Staski, E. (1998). Change and inertia on the frontier: Archaeology at the Paraje de San Diego, Camino Real, in southern New Mexico. International Journal of Historical Archaeology 2: 21-44.

Staski, E. (2005). An archaeological survey of El Camino Real de Tierra Adentro, Las Cruces-El Paso. International Journal of Historical Archaeology 8: 231-245.

Staski, E., and Reiter, J. (1996). Status and adobe quality at Fort Fillmore, New Mexico: Old questions, new techniques. Historical Archaeology 30(3): 1-19.

Steward, J. (1955). Theory of Culture Change: The Methodology of Multilinear Evolution, University of Illinois Press, Urbana.

Stewart, R. W. (2005). American Military History: The United States Army and the Forging of a Nation, 1775-1917, U.S. Government Printing Office, Washington, DC.

Stoffle, R. W., Zedeño, M. N., and Halmo, D. B. (eds.) (2001). American Indians and the Nevada Test Site: A Model of Research and Consultation, US Government Printing Office, Washington, DC.

Sudbury, J. B. (2009). Politics of the Fur Trade: Clay Tobacco Pipes at Fort Union Trading Post (32WI17), Clay Pipes Press, Ponca City, OK.

Sweitz, S. R. (2012). Consumer strategy and household consumption in the Cripple Creek Mining District, Colorado, USA. International Journal of Historical Archaeology 16: 227-266.

Tainter, J. A. (2000). Global change, history, and sustainability. In McIntosh, J., Tainter, J. A., and McIntosh, S. K. (eds.), The Way the Wind Blows: Climate, History, and Human Action, Columbia University Press, New York, pp. 331-356.

Tarka, S. A. (2007). My brother the buffalo: An ethnohistorical documentation of the 1999 Buffalo Walk and the cultural significance of Yellowstone buffalo to the Lakota Sioux and the Nez Perce peoples. Masters thesis, Department of Anthropology, University of Montana, Missoula.

Taylor, Q. (1998). In Search of the Racial Frontier: African Americans in the American West 1528-1990, W. W. Norton, New York.

Taylor, Q. (2000). African American Men in the American West, 1528-1990. Annals of the American Academy of Political and Social Science 569: 102-119.

Thackeray, L. (2012). 2,000-year-old bison bone site mired in controversy. Billings Gazette, October 24, 2012.

Thiel, J. H. (2002). Enlightening the past: The Phoenix Illuminating Gas and Electric Light Company. Industrial Archeology 28: 15-23.

Thomas, D. H. (ed.) (1989). Columbian Consequences, Vol. 1, Archaeological and Historical Perspectives on the Spanish Borderlands West, Smithsonian Institution Press, Washington, DC.

Thomas, D. H. (2000). Skull Wars: Kennewick Man, Archaeology, and the Battle for Native American Identity, Basic Books, Perseus Book Group, New York.

Thomas, D. H. (2005). The feeling of working completely in the dark. In Cordell, L. S., and Fowler, D. D. (eds.), The Uncertain Foundations of Southwestern Mission Archaeology in Current Views on the American Southwest, University of Utah Press, Salt Lake City, pp. 204-219.

Thornton, T. F. (2011). Already here and rich: A brief ethnohistory of Upper Lynn Canal. In Spude, C. H., Mills, R. O., Gurcke, K., and Sprague, R. (eds.), Eldorado! The Archaeology of Gold Mining in the Far North, University of Nebraska Press, Lincoln, pp. 95-108.

Thurlo, M. A. (2010). Masculine domesticity in the mining West: An archaeological investigation at Coloma ghost town. Masters thesis, Department of Anthropology, University of Montana, Missoula.

Timmons, M. A. (2007). Community archaeology: An application to heritage studies of western American mining settlements. Paper presented at the Australian Society for Historical Archaeology Conference, Sydney, Australia.

Timmons, M. A., and Dixon, K. J. (2014). Coloma Mining District: Gold Mining, Community, and Cultural Landscapes in Western Montana's Garnet Range. Industrial Archeology 38(1) (in press).

Towner, R. H., and Creasman, P. P. (2010). Historical dendroarchaeology in the El Malpais area: Lessons from the Savage homestead. Historical Archaeology 44(2): 8-27. 
Trigg, H. (2004). Food choice and social identity in early colonial New Mexico. Journal of the Southwest 46: $223-252$.

Truett, S. (2004). The ghosts of frontiers past: Making and unmaking space in the borderlands. Journal of the Southwest 46: 309-350.

Tsuli, L. J., and Ho, E. (2002). Traditional environmental knowledge and Western science: In search of common ground. Canadian Journal of Native Studies XXII 2: 327-360.

Turner, F. J. (1893). The significance of the frontier in American history. Lecture delivered to the American Historical Association, World's Columbian Exposition, Chicago.

Turner, N. J., Ignace, M. B., and Ignace, R. (2000). Traditional ecological knowledge and wisdom of Aboriginal peoples of British Columbia. Ecological Applications 10: 1275-1287.

Turpin, S. A. (1989). The iconography of contact: Spanish influence on the rock art of the Middle Rio Grande. In Thomas, D. H. (ed.), Columbian Consequences, Vol. 1, Archaeological and Historical Perspectives on the Spanish Borderlands West, Smithsonian Institution Press, Washington, DC, pp. 277-299.

Urbaniak, T. R., and Rust, T. (2009). The history and preservation of a historic inscription from Capitol Rock National Natural Landmark. Archaeology in Montana 50(2): 43-51.

Van Bueren, T. M. (2002). Struggling with class relations at a Los Angeles aqueduct construction camp. Historical Archaeology 36(3): 28-43.

Van Bueren, T. M. (2004). The "poor man's mill”: A rich vernacular legacy. Industrial Archeology 30: 5-23.

Van Bueren, T. M. (2008). Late-nineteenth-century Chinese farm workers in the California Mother Lode. Historical Archaeology 42(3): 80-96.

Van Bueren, T. M., Marvin, J., Psota, S., and Stoyka, M. (1999). Building the Los Angeles aqueduct: Archaeological data recovery at the Alabama Gates construction camp. Report to Environmental Analysis Branch, Headquarters, California Department of Transportation, Sacramento.

Van Kirk, S. (1984). The role of native women in the fur trade society of western Canada, 1670-1830. Frontiers: A Journal of Women Studies 7: 9-13.

Van Tilberg, H. K. (2007). Chinese Junks on the Pacific: Views from a Different Deck, University Press of Florida, Gainesville.

Veltre, D. W., and McCartney, A. P. (2002). Russian exploitation of Aleuts and fur seals: The archaeology of eighteenth and early-nineteenth-century settlements in the Pribilof Islands, Alaska. Historical Archaeology 36(3): 8-17.

Villalpando, M. E. (ed.) (2002). Boundaries and Territories: Prehistory of the U.S. Southwest and Northern Mexico, Anthropological Research Papers No. 54, Arizona State University, Tempe.

Voss, B. L. (2005). The archaeology of overseas Chinese communities. World Archaeology 37: 424-439.

Voss, B. L. (2008a). Between the household and the world system: Social collectivity and community agency in Overseas Chinese Archaeology. Historical Archaeology 42(3): 37-52.

Voss, B. L. (2008b). The Archaeology of Ethnogenesis: Race and Sexuality in Colonial San Francisco, University of California Press, Berkeley.

Voss, B. L. (2012). Status and ceramics in Spanish colonial archaeology. Historical Archaeology 46(2): 39-54.

Voss, B. L., and Allen, R. (2008). Overseas Chinese archaeology: Historical foundations, current reflections, and new directions. Historical Archaeology 42(3): 5-28.

Voss, B. L., and Williams, B. (eds.) (2008). Overseas Chinese archaeology. Historical Archaeology (thematic issue) 42(3): 1-193.

Wakeman, J., and Laumbach, K. (1997). Victorio's escape: GPS and archaeology recount the tale of an Apache battle. GPS World 8: 22-31.

Walker, M. (2003). The Ludlow Massacre: Class, warfare, and historical memory in southern Colorado. Historical Archaeology 37(3): 66-80.

Walker, M., and Saitta, D. J. (2002). Teaching the craft of archaeology: Theory, practice, and the field school. International Journal of Historical Archaeology 6: 199-207.

Wallerstein, I. (1974). The Modern World System, Academic Press, New York.

Wallerstein, I. (1980). The Modern World System II, Academic Press, New York.

Warner, M. S., and Baldwin, D. (2004). Building ties: The collaboration between the Miami Nation and archaeology. In Shackel, P. A., and Chambers, E. (eds.), Places in Mind: Archaeology as Applied Anthropology, Routledge, London, pp. 137-152.

Watkins, J. E. (2000). Indigenous Archaeology, AltaMira Press, Walnut Creek, CA. 
Watkins, J. E. (2003). Beyond the margin: American Indians, first nationals, and archaeology in North America. American Antiquity 68: 273-285.

Watts, D. (2007). A twenty-first-century science. Nature 4451: 489.

Wegars, P. W. (1991). Who's been workin' on the railroad?: An examination of the construction, distribution, and ethnic origins of domed rock ovens on railroad-related sites. Historical Archaeology 25(1): 37-65.

Wegars, P. W. (2003). Polly Bemis: An American Pioneer, Backeddy Books, Cambridge, ID.

Wegars, P. W. (ed.) (1993). Hidden Heritage: Historical Archaeology of the Overseas Chinese, Baywood, Amityville, NY.

Weisiger, M. (2004). The origins of Navajo pastoralism. Journal of the Southwest 46: 253-282.

Welch, J., and Stekler, P. (2007). Killing Custer: The Battle of Little Bighorn and the Fate of the Plains Indians, W.W. Norton, New York.

West, E. (1979). The Saloon on the Rocky Mountain Mining Frontier, University of Nebraska Press, Lincoln.

West, E. (1994). American frontier. In Milner, C. A., O’Connor, C. A., and Sandweiss, M. A. (eds.), The Oxford History of the American West, Oxford University Press, New York, pp. 115-149.

West, E. (1998). The Contested Plains: Indians, Goldseekers, and the Rush to Colorado, University Press of Kansas, Lawrence.

Whitacre, C. (2005). The search for the site of the Sand Creek Massacre. In Gulliford, A. (ed.), Preserving Western History, University of New Mexico Press, Albuquerque, pp. 175-188.

White, C. L. (2012). At home during the Depression in Rabbithole Springs, Nevada, US. Home Cultures 9(1): 57-76.

White, C. L. (2013). The Burning Man festival and the archaeology of ephemeral and temporary gatherings. In Harrison, R., Graves-Brown, P., and Piccini, A. (eds.), Oxford Handbook of the Archaeology of the Contemporary World, Oxford University Press, Oxford, UK, pp. 591-605.

White, P. J. (2003). Heads, tails, and decisions in-between: The archaeology of mining wastes. Industrial Archeology 26: 47-66.

White, P. J. (2006). Troubled waters: Timbisha Shoshone, miners, and dispossession at Warm Spring. Industrial Archeology 32: 5-24.

White, R. (1991a). It's Your Misfortune and None of My Own: A New History of the American West, University of Oklahoma Press, Norman.

White, R. (1991b). Trashing the trails. In Limerick, P. N., Milner II, C. A., and Rankin, C. E. (eds.), Trails: Towards a New Western History, University Press of Kansas, Lawrence, pp. 26-39.

White, W. G., James, R. M., and Bernstein, R. (eds.) (1991). Nevada Comprehensive Preservation Plan, Nevada Division of Historic Preservation and Archeology, Carson City, NV.

Wilcox, M. V. (2002). Social memory and the Pueblo Revolt: A postcolonial perspective. In Preucel, R. W. (ed.), Archaeologies of the Pueblo Revolt: Identity, Meaning, and Renewal in the Pueblo World, University of New Mexico Press, Albuquerque, pp. 167-180.

Wilcox, M. V. (2009). The Pueblo Revolt and the Mythology of Conquest: An Indigenous Archaeology of Contact, University of California Press, Berkeley.

Wilcox, M. V. (2010a). Saving indigenous people from ourselves: Separate but equal archaeology is not scientific archaeology. American Antiquity 75: 221-227.

Wilcox, M. V. (2010b). Marketing conquest and the vanishing Indian: An indigenous response to Jared Diamond's, Guns, Germs, and Steel and Collapse. Journal of Social Archaeology 10: 92-117.

Wilds, L. J. (2010). Water Politics in Northern Nevada: A Century of Struggle, University of Nevada Press, Reno.

Wilkie, L. A. (2010). The Lost Boys of Zeta Psi: A Historical Archaeology of Masculinity at a University Fraternity, University of California Press, Berkeley.

Willey, P., and Hardesty, D. L. (2000). "Our trubels geting to Callifornia": The Donner party, the Sierra Nevada mountains, and the winter of 1846-47. Proceedings of the American Academy of Forensic Sciences VI: 294.

Williams, J. C. (1996). California's first high-head turbine installation. Industrial Archeology 22: 51-64.

Wolf, E. R. (1982). Europe and the People Without History, University of California Press, Berkeley.

Wood, M. C. (2004). Working-class households as sites of social change. In Barile, K., and Brandon, J. C. (eds.), Household Chores and Household Choices: Theorizing the Domestic Sphere in Historical Archaeology, University of Alabama Press, Tuscaloosa, pp. 210-232.

Wood, M. C., Carrillo, R. F., McBride, T., Bryant, D. L., and Convery, W. J., III. (1999). Historical archaeological testing and data recovery for the Broadway Viaduct Replacement Project, downtown 
Denver, Colorado: Mitigation of site 5DV5997. SWCA Archaeological Report No. 99-308, submitted to the Colorado Department of Transportation, Office of Environmental Services, Denver.

Wooden Leg (2003). Wooden Leg: A Warrior Who Fought Custer, Marquis, T. B., interpreter, University of Nebraska Press, Lincoln.

Woods, R. B. (1983). Integration or segregation? The color line in Kansas, 1878-1900. Western Historical Quarterly 14: 181-198.

Woodward, A. (1958). Fort Union, New Mexico-Guardian of the Santa Fe Trail. Ms. on file, National Park Service, Sante Fe, NM.

Worster, D. (1991). Beyond the agrarian myth. In Limerick, P. N., Milner II, C. A., and Rankin, C. E. (eds.), Trails: Towards a New Western History, University Press of Kansas, Lawrence, pp. 3-25.

Worster, D. (1992). Rivers of Empire: Water, Aridity, and the Growth of the American West, Oxford University Press, New York.

Worster, D. (1994). The Wealth of Nature: Environmental History and the Ecological Imagination, Oxford University Press, New York.

Wrobel, D. M., and Steiner, M. C. (1997). Many Wests: Place, Culture, and Regional Identity, University Press of Kansas, Lawrence.

Wylie, A. (1993). Invented lands/discovered pasts: The westward expansion of myth and history. Historical Archaeology 27(4): 1-19.

Yang, J. K., and Hellman, V. R. (1998). What's in the pot? An emic study of Chinese brown glazed stoneware. Proceedings of the Society for California Archaeology 11: 59-66.

Yoffee, N., and Crowell, B. (2006). Excavating Asian History: Interdisciplinary Studies in Archaeology and History, University of Arizona Press, Tucson.

Zappia, N. A. (2012). Indigenous borderlands: Livestock, captivity, and power in the far West. Pacific Historical Review 81: 193-220.

Zedeño, M. N. (2007). Blackfeet landscape knowledge and the Badger-Two Medicine traditional cultural district. The SAA Archaeological Record 7(2): 9-12, 22.

Zedeño, M. N., and Bowser, B. J. (2009). The archaeology of meaningful places. In Bowser, B. J., and Zedeño, M. N. (eds.), The Archaeology of Meaningful Places, University of Utah Press, Salt Lake City, pp. 1-14.

Ziesing, G. (ed.) (1997). From Rancho to Reservoir: History and Archaeology of the Los Vaqueros Watershed, California, Anthropological Studies Center, Sonoma State University, Rohnert Park, CA.

Zimmerman, L. J. (2007). Plains Indians and resistance to "public" heritage commemoration of their pasts. In Silverman, H., and Ruggles, D. F. (eds.), Cultural Heritage and Human Rights, Springer, New York, pp. 144-158.

\section{Bibliography of recent literature}

Bernstein, M. (2006). Industrial archeology and environmental assessments. Industrial Archeology 32(1): 25-51.

Burley, D. V., and Will, M. H. (2000). "The beer that made Klondike famous and Milwaukee jealous": The O'Brien Brewing and Malting Company site, Klondike City, Yukon. Industrial Archeology 26(1): 37-54.

Chen, Y. (2001). In the Colonies of Tang: Historical archaeology of Chinese Communities in the Northern Cariboo District, British Columbia (1860s-1940s), Ph.D. dissertation, Department of Archaeology, Simon Fraser University, Burnaby, British Columbia.

Crist, T. (2006). The good, the bad, and the ugly: Bioarchaeology and the modern gun culture debate. Historical Archaeology 40(3): 109-130.

Diehl, M., Waters, J. A., and Thiel, J. H. (1998). Acculturation and the composition of the diet of Tucson's Overseas Chinese gardeners at the turn of the century. Historical Archaeology 32(4): 19-33.

Ellis, M. A. B., Merritt, C. W., Novak, S. A., and Dixon, K. J. (2010). The signature of starvation: A comparison of bone processing at a Chinese encampment in Montana and the Donner Party camp in California. Historical Archaeology 45(2): 97-112. 
Fliess, K. H. (2000). There's gold in them thar - documents?: The demographic evolution of Nevada's Comstock, 1860 through 1910, and the intersection of census demography and historical archaeology. Historical Archaeology 34(2): 65-88.

Frink, L. M. (2009). The social role of technology in coastal Alaska. International Journal of Historical Archaeology 13: 282-302.

Gale, S. J., and Haworth, R. J. (2002). Beyond the limits of location: Human environmental disturbance prior to official European contact in early colonial Australia. Archaeology in Oceania 37: 123-136.

Gillespie, W. B., and Farrell, M. B. (2002). Work camp settlement patterns: Landscape-scale comparisons of two mining camps in southeastern Arizona. Historical Archaeology 36(3): 59-68.

Gilfoyle, T. J. (2005). Archaeologists in the brothel: "Sin City," historical archaeology and prostitution. Historical Archaeology 39(1): 133-141.

Goddard, R. A. (2002). Nothing but tar paper shacks. Historical Archaeology 36(3): 85-93.

Guilliford, A. (ed.) (2005). Preserving Western History, University of New Mexico Press, Albuquerque.

Hardesty, D. L. (1999). Historical archaeology in the next millennium: A forum and response to comments by Gray, Lees, and Schuyler. Historical Archaeology 33(2): 51-58, 71-72.

Hardesty, D. L. (2000). Speaking in tongues: The multiple voices of fieldwork in Industrial Archeology. Industrial Archeology 26(2): 43-47.

Hardesty, D. L. (2002). Commentary: Interpreting variability and change in western work camps. Historical Archaeology 36(3): 94-98.

Hardesty, D. L., and Little, B. J. (2000). Assessing Site Significance: A Guide for Archaeologists and Historians, AltaMira Press, Walnut Creek, CA.

Jones, T. L., and Perry, J. E. (eds.) (2012). Contemporary Issues in California Archaeology, Left Coast Press, Walnut Creek, CA.

Justio, C., and Brown, C. W. (2011). Montana's barns: A vanishing history. Montana: The Magazine of Western History 61(3): 38-56.

Kardatzke, T. A. (2002). Archaeological Excavations in Skagway, Alaska, Vol. 9, Excavations at the Pantheon Saloon Complex, National Park Service, Skagway, AK.

Lambert, P. M. (2002). The archaeology of war: A North American perspective. Journal of Archaeological Research 10: 207-241.

Liebmann, M., and Murphy, M. S. (eds.) (2010). Rethinking the Archaeology of Resistance to Spanish Colonialism in the Americas, School for Advanced Research Press, Santa Fe, NM.

Lydon, J. (2006). Pacific encounters, or beyond the islands of history. In Hall, M., and Silliman, S.W. (eds.), Historical Archaeology, Blackwell, Malden, MA, pp. 293-312.

Mason, R. J. (2006). Inconstant Companions: Archaeology and North American Indian Oral Tradition, University of Alabama Press, Tuscaloosa.

McGuire, R. H., and Navarrete, R. (2005). Between motorcycles and rifles: Anglo-American and Latin American radical archaeologies. In Funari, P. P., Zarankin, A., and Stovel, E. (eds.), Global Archaeological Theory: Contextual Voices and Contemporary Thoughts, Kluwer Academic/Plenum, New York, pp. 309-336.

McGuire, R. H., and Reckner, P. (2003). Building a working class archaeology: The Colorado Coal Field War project. Industrial Archeology Review 25: 83-95.

Milner, G. R. (2005). Nineteenth-century arrow wounds and perceptions of prehistoric warfare. American Antiquity 70:144-156.

Newman, E. T. (2010). Butchers and shamans: Zooarchaeology in a central Mexican hacienda. Historical Archaeology 44(2): 35-50.

Novak, S. A., and Rodseth, L. (2006). Remembering Mountain Meadows: Collective violence and the manipulation of social boundaries. Journal of Anthropological Research 61: 1-25.

Owsley, D. W., Brooks, B. E., and Melton, T. (2006). Search for the grave of William Preston Longley, hanged Texas gunfighter. Historical Archaeology 40(3): 50-63.

Paterson, A. (2003). The texture of agency: An example of culture-contact in central Australia. Archaeology in Oceania 38: 52-65.

Psota, S. (2002). Boss of the Road: Early-20th-century consumer selections of work clothing from Alabama Gates Work Camp, Owens Valley, California. Historical Archaeology 36(4): 111-128.

Psota, S. (2011). The archaeology of mental illness from the afflicted and caretaker perspective: A northern California family's odyssey. Historical Archaeology 45(4): 20-38.

Praetzellis, A., and Praetzellis, M. (2011). Cultural resource management archaeology and heritage values. Historical Archaeology 45(1): 86-100. 
Purser, M. (1999). Ex occidente lux? An archaeology of later capitalism in the nineteenth-century west. In Leone, M. P., and Potter, P. B., Jr. (eds.), Historical Archaeologies of Capitalism, Kluwer Academic/Plenum, New York, pp. 115-141.

Rautman, A. E., and Fenton, T. W. (2005). A case of historic cannibalism in the American West: Implications for southwestern archaeology. American Antiquity 70: 321-341.

Reid, J., and Whittlesey Rodriguez-Alegria, E. (2010). Incumbents and challengers: Indigenous politics and the adoption of Spanish material culture in colonial Xaltocan, Mexico. Historical Archaeology 44(2): 51-71.

Schuyler, R. L. (1991). Historical archaeology in the American West: The view from Philadelphia. Historical Archaeology 25(3): 7-17.

Smits, N. J. (2008). Roots entwined: Archaeology of an urban Chinese cemetery. Historical Archaeology 42(3): 111-122.

Sperry, E. (2012). The politics of performance: Montana's landless Indians and Beveridge's Montana Wildest West Show. Montana: The Magazine of Western History 62(1): 48-64.

Tingley, J., Lugaski, T., and McLane, A. (2001). Discovery of mining camps in south-central Nevada. The Mining History Journal 8: 18-29.

Van Bueren, T. M. (2002). The changing face of work in the West: Some introductory comments. Historical Archaeology 36(3): 1-7.

Voss, B. L. (2008). Poor people in silk shirts: Dress and ethnogenesis in Spanish-colonial San Francisco. Journal of Social Archaeology 8: 404-432.

Voss, B. L. (2008). Gender, race, and labor in the archaeology of the Spanish-colonial Americas. Current Anthropology 49: 861-897.

Walter, T. L. (2006). Esprítu Santo de Zúñiga: A Frontier Mission in South Texas, University of Texas Press, Austin.

Wegars, P. W. (2008). The Asian American Comparative Collection: A unique resource for archaeologists and historians. Historical Archaeology 42(3): 166-170.

White, P. S. (2010). The rise and fall of the California stamp: Historical and archaeological perspectives on the aging of a technology. Industrial Archeology 36(1): 64-83.

Williams, B. (2008). Chinese masculinities and material culture. Historical Archaeology 42(3): 53-67.

Yu, C. Y. (2008). On tracking Ниа Kiи: A Chinese American historian's view. Historical Archaeology 42(3): 158-163. 